\title{
POST-INDUSTRIAL IMAGINARIES:
}

\section{NATURE, REPRESENTATION, AND RUIN IN DETROIT, MICHIGAN}

\author{
by \\ Nate Millington \\ A thesis submitted in partial fulfillment of \\ the requirements for the degree of Master of Science
}

(Geography)

at the

UNIVERSITY OF WISCONSIN-MADISON

2010 



\section{Table of Contents}

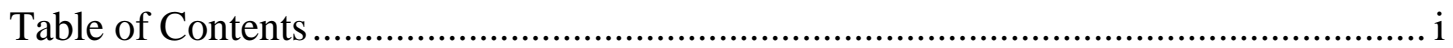

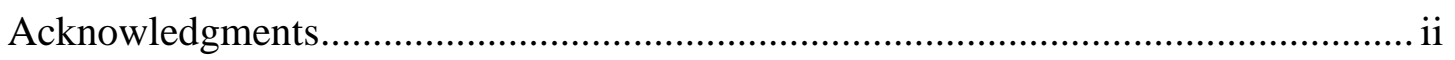

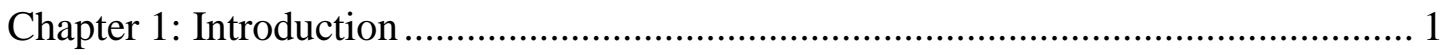

Chapter 2: Literature Review and Methodology ................................................... 4

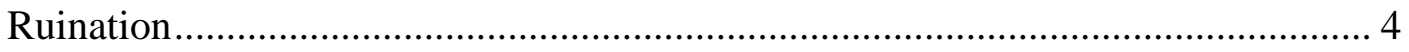

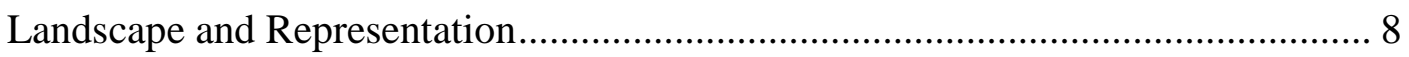

Critical Approaches to Photography ......................................................... 15

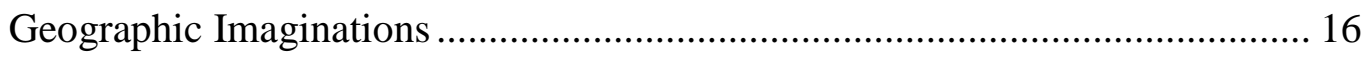

Image and Urban Redevelopment........................................................ 19

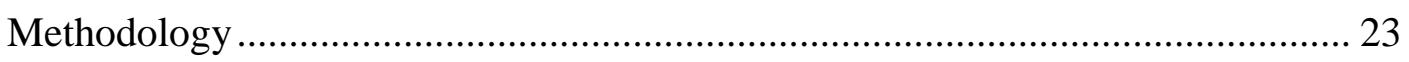

Chapter Three: Envisioning Detroit: Ruin Imaginaries, the Michigan Central Station,

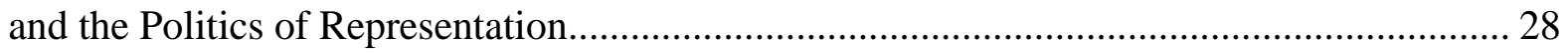

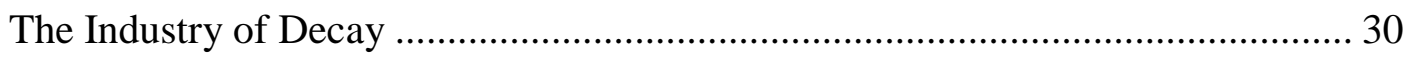

The Michigan Central Station ................................................................... 47

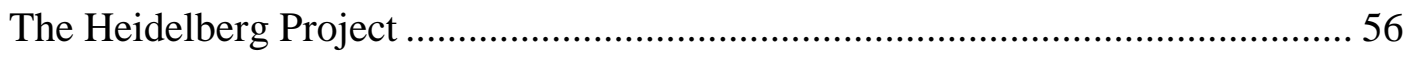

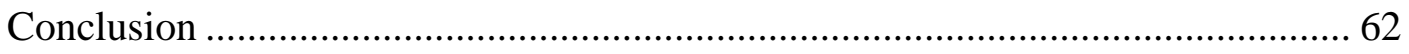

Chapter 4: "Wild Wild Midwest": Landscape and Nature in Detroit......................... 64

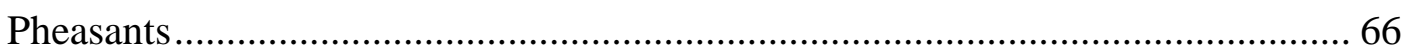

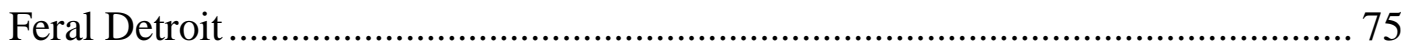

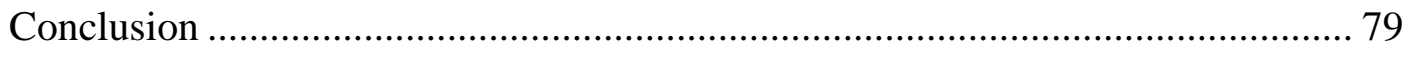

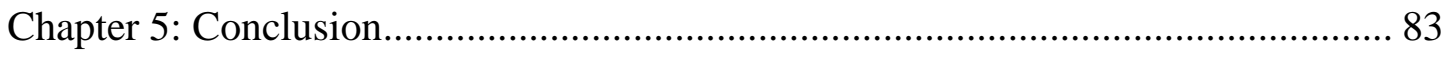

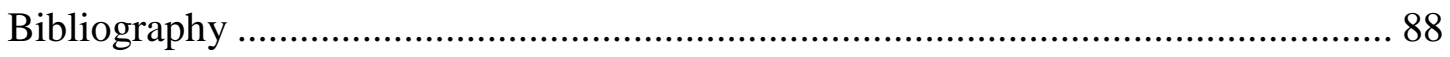




\section{Acknowledgments}

Writing this thesis has been a collective affair, and I am indebted to many. I first need to thank my adviser, Kris Olds, for help throughout this project and throughout my time at UW-Madison. Additionally, my committee members, Anna Andrzejewski and William Cronon, read versions of this thesis and contributed invaluable advice. Matt Turner read multiple versions of this thesis when it was still just a proposal, and his comments and feedback were crucial for the development of this project. Finally, Alfonso Morales and Keith Woodward gave me support and advice throughout my time at UW-Madison. .

Additionally, graduate students in the Geography department were an invaluable resource as I developed and cohered this project. I am particularly grateful for the help of Chris Muellerleile, Adam Mandelman, Emma Schroeder, Sigrid Peterson, Bilal Butt, Jake Fleming, Sarah Bennett, Leif Brottem, and Jason $\mathrm{Nu}$ for not just advice but also friendship as I navigated the strange world of graduate school. Finally, I would not have written this thesis without the invaluable support of Paddy Rourke, Tom Tews, and Sharon Kahn, who made every trip into science hall a delight.

A special thanks goes to the many photographers who gave me permission to reproduce their work, and I am grateful for their generosity. This project was strengthened by their willingness to engage in substantive conversation about the work they do.

Of course, all errors, omissions and interpretations are entirely my own. 


\section{Chapter 1: Introduction}

In a December 2008 photo essay in Time, artist Sean Hemmerle displays a series of photographs entitled "The Remains of Detroit". In a set of eleven images, he highlights two of the primary icons used to represent the city: cavernous empty auto plants alongside houses being overtaken by nature, the supposed return to the historic Midwestern prairie. ${ }^{1}$

Hemmerle's photographs are one piece of a broader industry focused on documenting Detroit's decaying cityscape. Increasingly over the past three decades, Detroit has become a popular site for journalists and amateur photographers interested in the city's so-called ruins ${ }^{2}$. This includes image sets produced locally_The Fabulous Ruins of Detroit and 100 Abandoned Houses are two such projects - alongside work produced by those from outside the city, like the work of French photographers Yves Marchand and Romain Meffre, photo essays in Life.com and Slate.com, as well as self-published accounts found on Youtube, Flickr, and personal websites. These images are not monolithic, and differences in tone and context convey different impressions and responses. Yet despite their stylistic distinctions, these images help to construct a particular mythology of the city that is focused on emptiness, ruin, and picturesque decay. They allow a variety of online readers and on-the-ground tourists to explore the romantic sublime of Detroit's ruins through letters to editors and comment pages on websites and blogs. Throughout, what animates this work and the

\footnotetext{
1 "The Remains of Detroit," Time.com, http://www.time.com/time/photogallery/0,29307,1864272_1810098,00.html (accessed December 20, 2008). ${ }^{2}$ I use this term with hesitation, as one of the central claims of this paper is that calling something a ruin is a subjective and often problematic assertion. As I will describe in more detail in the pages to come, many of Detroit's supposed ruins are in fact lived in or privately owned.
} 
responses to it is a feeling of deep ambiguity, as commentators both mourn the city's current state while celebrating its picturesque aesthetic. This tension is fundamental to both the production and reception of these images, and gestures at some of the ways in which these photographs reflect broader cultural anxieties about deindustrialization, urban decline and the emergence of particularly new kinds of urban ecologies in cities like Detroit.

In the pages to follow, I examine representations made of Detroit, with a focus on images made over the past two years. ${ }^{3}$ I do this in order to assess how these images work as material objects that circulate inside and outside of the city, as well as what they say about broader anxieties on the part of people who view the images. My ultimate interest is in the intersections between landscape representation and landscape morphology, and this thesis is an attempt at assessing how representations filter back into the material or lived spaces of the city. After a chapter in which I describe the sets of literatures I engaged with while developing this paper, I split the analysis into two related case studies. In the first, I analyze the idea of Detroit's ruins in a broad sense. I argue that images of Detroit work to naturalize the city's decline and erase its residents through a focus on the city's aesthetic appeal. By resigning the city to a ruin, Detroit's cataloguers help to create a break with the city's present in favor of overwrought pronouncements about inevitability and material decay. I focus on two sites in the city—-the Michigan Central Station and Tyree Guyton's Heidelberg Projectin order to deepen the analysis. In the next chapter, I focus on representations that suggest

\footnotetext{
${ }^{3}$ I use the word representation to refer to both photographs as well as written accounts. Many of the photographs I look at are part of broader projects, such as books, websites or newspaper articles, and so I use both types of representation interchangeably and often in tandem.
} 
Detroit is returning to nature. I argue that these images further help to obscure Detroit's present by pulling on conceptions of the natural world as that which exists outside of human life. Through recourse to a version of the nonhuman world that stresses what Bill Cronon has called the "wilderness ethic," photographers and journalists reduce the complicated ecologies emerging in Detroit to a vague story of natural reclamation. ${ }^{4}$

But I conclude by focusing on the extent to which these images suggest new urban formulations that have not yet been adequately theorized. As conventional narratives suggest, Detroit is a declining city, but it is also a city in the making. Finding new stories to tell about Detroit is a way of constructing new theorizations and imaginaries of post-industrial cities more broadly. Detroit will never be what it once was, but it is also not a dead city. Instead, the kinds of ecologies and spatialities emerging from places like Detroit suggest that we need to rethink how we conceptualize urban places. Finding stories to tell about the city that gesture at the interrelations between race, representation and, importantly, ecology, is a crucial project for urban geographers interested in understanding the post-industrial metropolis.

${ }^{4}$ William Cronon, "The Trouble with Wilderness, or, Getting Back to the Wrong Nature," in Uncommon Ground: Rethinking the Human Place in Nature, ed. William Cronon (New York: W.W. Norton \& Co., 1995), 6990. 


\section{Chapter 2: Literature Review and Methodology}

This literature review is roughly divided into three overlapping sets of literatures that I engaged with while cohering this project. In the first section, I focus on recent interest in the idea of ruination and material decay, which partially explains the recent popularity of images made of Detroit's decline. In the second, I deal with the intersections between representation and the Cultural Landscape. Finally, I focus on critical analyses of photography, as a part of post-colonial scholarship and critical work on urban redevelopment.

\section{Ruination}

The recent popular interest in Detroit's ruins mirrors a scholarly resurgence of the idea of ruination, both within and outside Geography. Like online commentators, scholars are often torn between revulsion and attraction when responding to images of ruins, a tension that is arguably central to the long traditions associated with ruin appreciation. For literary critic Andreas Huyssen, a "cult of ruins" has gripped Western modernity "in waves since the eighteenth century." But "over the past decade and a half, a strange obsession with ruins has developed in the countries of the northern transatlantic as part of a much broader discourse about memory and trauma, genocide and war." ${ }^{, 5}$ Hussen ties modern ruins to nostalgia for past industrial certainties on the part of the west, yet he is careful to leave open the inherent ambiguity of ruination. Ruins, to Huyssen, allow for the "hardly nostalgic consciousness of the transitoriness of all greatness and power, the warning of imperial hubris, and the

\footnotetext{
5 Andreas Huyssen, “Nostalgia for Ruins," Grey Room 23 (Spring 2006): 7.
} 
remembrance of nature in all culture." Similarly, in his 1911 essay, "The Ruin," Georg Simmel argues that the ruin represents an encounter between a Hegelian will constantly striving and the "downward-dragging, corroding, crumbling power of nature."7 For Simmel, the "form of the soul" is dictated by this struggle between nature and culture, something that the ruin preserves in a "profound peace." ${ }^{8}$ He notes:

The aesthetic value of the ruin combines the disharmony, the eternal becoming of the soul struggling against itself, with the satisfaction of form, the firm limitedness, of the work of art. ${ }^{9}$

Ruins are articulations of the battle between nature and culture that Simmel argues resides within all people.

This nature/culture binary espoused by Simmel is obviously outside of current intellectual favor, yet echoes of it can be heard in recent work on ruin. Tim Edensor sees industrial ruins as sites that serve to "confound the binaries between urban-human and rural'natural.","10 He argues that conventional accounts of ruins pull from two intellectual traditions: romantic, aesthetic approaches and a more contemporary "modern gothic." Both stress melancholy and gloominess, whereas Edensor himself is more interested in the "hybridities and transgressive spatialities of ruins." He conceives of them as sites that "gesture towards the present and the future as temporal frames which can be read as both

\footnotetext{
${ }^{6}$ Huyssen, "Nostalgia for Ruins," 13.

${ }^{7}$ Georg Simmel, "The Ruin," in Georg Simmel, 1858-1918: A Collection of Essays, with Translations and a Bibliography, ed. Kurt H. Wolfe (Columbus, OH: Ohio State University Press, 1959), 261.

${ }^{8}$ Simmel,"The Ruin," 265.

${ }^{9}$ Ibid.

${ }^{10}$ Tim Edensor, Industrial Ruins: Spaces, Aesthetics and Materiality (Oxford: Berg, 2005), 51.
} 
dystopian and utopian." "In his other work on ruins, Edensor conceptualizes them as a means of disordering normative conceptions of materiality and time. ${ }^{12}$ Similarly, Caitlin DeSilvey has stressed an approach to historical interpretation that uses decay as a means of uncovering historical knowledge. She does this by understanding the artifact not as a "discrete entity but a material form bound into continual cycles of articulation and disarticulation." ${ }^{13}$ Other approaches to ruination can be found in more popular sources, which generally highlight many sites found in Detroit. ${ }^{14}$

George Steinmetz has undeniably done the most to analyze the particularities of Detroit's ruins. In his 2008 essay, "Harrowed Landscapes: White Ruingazers in Namibia and Detroit and the Cultivation of Memory," he articulates Detroit's ruins as a product of what he calls a "nostalgia for Fordism" on the part of Suburban Detroiters. He agrees with DeSilvey that "perhaps these ruins are even more evocative than fully-restored buildings, which tend to present a more predictable, pre-interpreted message." ${ }^{\prime 15}$ Yet for Steinmetz, suburban Detroiters are not using ruins as a way of merging temporal categories; instead, they "do not

\footnotetext{
${ }^{11}$ Edensor, Industrial Ruins, 15.

${ }^{12}$ See Tim Edensor, "Waste Matter - The Debris of Industrial Ruins and the Disordering of the Material World," Journal of Material Culture 10, no. 3 (2005): 311-332; Tim Edensor, "The Ghosts of Industrial Ruins: Ordering and Disordering Memory in Excessive Space," Environment and Planning D: Society and Space 23 (2005): 829-849.

${ }^{13}$ Caitlin DeSilvey, “Observed Decay: Telling Stories with Mutable Things," Journal of Material Culture 11, no. 3 (2006): 335. See also Caitlin DeSilvey, "Salvage Memory: Constellating Material Histories on a Hardscrabble Homestead," Cultural Geographies 14, no. 3 (2007): 401-424; Caitlin DeSilvey, "Art and archive: Memory-work on a Montana Homestead," Journal of Historical Geography 33 2007), 878-900.

${ }^{14}$ See Harry Skrdla, Ghostly Ruins: America's Forgotten Architecture (New York: Princeton Architectural Press, 2006).

${ }^{15}$ George Steinmetz, "Harrowed Landscapes: White Ruingazers in Namibia and Detroit and the Cultivation of Memory, Visual Studies 23, no. 3 (December 2008), 232.
} 
seem confused about the unidirectionality of time's arrow."16 For Steinmetz's subjects, Detroit is ultimately located in the past. Derek Gregory similarly looks at how European travelers to colonial Egypt were able to both depopulate contemporary landscapes of residents while also repopulating them with historic presences: ruins. ${ }^{17}$ For Gregory, trips to nineteenth-century Egypt were often conceived as trips into the past itself. Images of Detroit are arguably embedded in a similar representational space that both obscures current residents while placing the city in a mythic historical context.

Literature on ruination is important in Detroit's case because material decay has become the dominant trope used to construct an imaginative geography of the city. Edensor's portrayal of the evocative power of ruin helps to explain the popular fascination with Detroit, although I am inclined to argue that this aesthetic and romanticized conception of ruination ignores the political dimension inherent in assigning something the label of ruin. For many in Detroit, the city is not a ruin; rather, it is home. ${ }^{18}$ And as Jerry Herron has argued, these ruins are not found but made. ${ }^{19}$ To call something a ruin, as many photographers and journalists do, is to frame a building in a particular way, one thick with romanticist connotations of inevitability and historical awe. In one particularly illuminating passage, photographer and sociologist Camilo José Vergara admits, after finding out that one of his supposed ruins was actually inhabited, "Left to decide whether or not the building was a ruin, I took another look

\footnotetext{
${ }^{16}$ Steinmetz, "Harrowed Landscapes," 232.

${ }^{17}$ Derek Gregory, "Between the Book and the Lamp: Imaginative Geographies of Egypt, 1849-50," Transactions of the Institute of British Geographers 20, no.1 (1995), 29-57.

${ }^{18}$ For this insight, I am grateful to Matthew Daley.

19 Jerry Herron, "Three Meditations on the Ruins of Detroit," in Stalking Detroit, ed. Georgia Daskalakis, Charles Waldheim, and Jason Young (Barcelona: Actar, 2002), 34.
} 
at the faded gold star against the black polished stone and decided that it was." ${ }^{20}$ Ruins need not be empty to be ruined - a point made by Simmel—but this anecdote gestures at the politics of description inherent in Vergara's argument. It is up to Vergara to decide what is and is not a ruin, despite his intentions to honor the strivings of his subjects, many of whom would rather not live in a city seen as ruin rather than home. Additionally, this anecdote gestures at the fact that many of these sites - the Michigan Central Station in particular-are decidedly not abandoned or inevitable; rather, they are privately owned, embroiled in lawsuits, or have been purchased as part of a multi-year development plan. They are products of particular political and economic processes that are ongoing. Trees growing in the rafters are not a sign of inevitable reclamation but the banalities of landlord neglect. As Herron argues:

...virtually no part of the abandoned downtown is not owned. Its uninhabited spaces are bought and sold frequently, and at a profit, by people whose intention is to do nothing with them except to take advantage of the opportunities afforded by institutionally sanctioned neglect in terms of tax write-offs, bankruptcy defaults, resale of architectural details and fittings, and so on. ${ }^{21}$

As I will argue throughout this paper, finding appreciation in Detroit's ruins is a kind of voyeurism that assumes a distance. Those who live beside and within the city's so-called ruins are often much less inclined to celebrate their unique aesthetic.

\section{Landscape and Representation}

${ }^{20}$ Camilo José Vergara, American Ruins (New York: Monacelli Press, 1999), 208.

${ }^{21}$ Herron, AfterCulture, 85. 
Much of the recent literature on ruination is focused on materiality and the experiential dynamics of abandoned buildings. For the purposes of this paper, however, I focused on the production and consumption of images made of Detroit's ruins, which allowed me to engage with a different set of literatures focused on the tension between representation and landscape morphology. In the case of Detroit, representations made of the city directly influence the city's morphology through the capacity of images to circulate, an insight I owe to the study of Material Culture broadly defined. Material Culture is a way to think about the power inherent in representation, and it enables researchers to move the question from "what do these images mean?" to "what do these images do?" But power and landscape have a difficult relationship, given that most cultural landscapes are a product of a multitude of actors and events and lack a single author. Finding ways of thinking about power was one of the central difficulties in this project, but it allowed me to ask questions about the role of landscape in the everyday reproduction of social life.

The North American Landscape tradition has long been open to questions of power and authorship in the construction of everyday landscapes. As Don Mitchell notes in his 1996 book, The Lie of the Land:

If we want to write spatial histories that have both intellectual and political import (and I do), then we cannot simply abandon the material field as if it does not exist... On the contrary, the relationship between material form and ideological representation must be the center of our examinations. ${ }^{22}$

\footnotetext{
${ }^{22}$ Don Mitchell, The Lie of the Land: Migrant Workers and the California Landscape (Minneapolis, MN: University of Minnesota Press, 1996).
} 
In framing my own arguments in this paper, I primarily relied on a particularly North American approach to landscape, drawn from the work of Richard Schein, Don Mitchell, and W.J.T. Mitchell, amongst others. Without ignoring the recent work in landscape that stresses phenomenological approaches, my interest lies in landscape as a material entity that serves to structure and naturalize social relations and cultural processes. In this, I echo W.J.T. Mitchell's 1994 assertion that:

Landscape as a cultural medium thus has a double role with respect to something like ideology: it naturalizes a cultural and social construction, representing an artificial world as if it were simply given and inevitable, and it also makes that representation operational by interpellating its beholder in some more or less determinate relation to its givenness as sight and site. ${ }^{23}$

The result, for Mitchell, is that scholars of landscape need to:

...trace the process by which landscape effaces its own readability and naturalizes itself and must understand that process in relationship to what might be called 'the natural histories' of its own beholders. ${ }^{24}$

This account of landscape — as what Marx calls a "social hieroglyph"—gestures

provocatively at intersections between representation and materiality. It stresses the fact that landscape painting is a kind of representation of a representation: As W.J.T. Mitchell notes, "landscape is already artifice in the moment of its beholding, long before it becomes the subject of pictorial representation. ${ }^{, 25}$ Here, echoes of Pierce Lewis' famous dictum that landscape is "our unwitting autobiography" can be found, but they are complicated by

\footnotetext{
${ }^{23}$ W.J.T. Mitchell, "Introduction," in Landscape and Power, ed. W.J.T. Mitchell (Chicago: The University of Chicago Press, 1994), 2.

${ }^{24}$ Mitchell, "Introduction," 2.

${ }^{25}$ W.J.T. Mitchell, “Imperial Landscape," in Landscape and Power, ed. W.J.T. Mitchell (Chicago: The University of Chicago Press, 1994), 14.
} 
Mitchell's insistence on the capacity of landscape to act, to travel, to be a verb rather than a noun. ${ }^{, 26}$ In these formulations, Mitchell prefigures work in landscape that stresses the processual character of landscapes that are never static. As Richard Schein argues:

Landscapes are always in the process of 'becoming,' no longer reified or concretized - inert and there - but continually under scrutiny, at once manipulable and manipulated, always subject to change, and everywhere implicated in the ongoing formulation of social life."27

Schein reiterates Mitchell's insistence that landscapes serve a naturalizing function. Particular landscapes - in their everyday, experiential form — are representations of the processes that created them, but their normative readability serves to naturalize the processes that construct them. To put it into Schein's terminology, “The cultural landscape serves to naturalize or concretize — to make normal—social relations." 28

A note on terminology and definition is important here, given the usage of the term naturalization throughout this literature. In his 1980 essay Ideas of Nature, Raymond Williams argues that the word "nature" is incredibly complex but also taken for granted. For Williams, "the idea of nature contains, though often unnoticed, an extraordinary amount of human history." 29 He attempts to differentiate between two taken-for-granted usages of the word: as a description of a physical site — " $a$ state of nature"-alongside the capacity of the

\footnotetext{
${ }^{26}$ Pierce Lewis, “Axioms for Reading the Landscape," in The Interpretation of Ordinary Landscapes, ed. D.W. Meinig (New York: Oxford University Press, 1979), 11-32.

${ }^{27}$ Richard H. Schein, "The Place of Landscape: A Conceptual Framework for Interpreting an American Scene," Annals of the Association of American Geographers 87, no. 4 (1997): 662.

${ }^{28}$ Richard H. Schein, "Normative Dimensions of Landscape," in Everyday America: Cultural Landscape Studies after J.B. Jackson, eds. Chris Wilson and Paul Groth (Berkeley: University of California Press, 2003 ), 203.

${ }^{29}$ Raymond Williams, "Ideas of Nature," in Culture and Materialism (London: Verso, 1980), 67.
} 
word to refer to the inherent essence of a thing or agreement. Yet Williams ultimately finds a common history for the two words in the work of natural science, noting:

The association and then the fusion of a name for the quality with a name for the things observed has a precise history. It is a central formation of idealist thought. What was being looked for in nature was an essential principle. The multiplicity of things, and of living processes, might then be mentally organized around a single essence or principle: a nature. ${ }^{, 30}$

Williams' essay is a guide for the entirety of this project, but for now I want to focus on how these different meanings of the word nature suggest different versions of how landscape functions. For Schein, landscape has a naturalizing dimension as a result of its normative materiality: landscape is capable of expressing "what ought to be. ${ }^{31}$ This gestures at Williams' second definition of the word nature, and assumes the process of naturalization to be a process by which landscapes come to be seen as normal. In his 1997 essay, "The Place of Landscape," Schein furthers this insight by conceptualizing landscapes as what he calls "discourse materialized," arguing that:

As a material component of a particular discourse or set of discourses, 'the cultural landscape' at once captures the intent and ideology of the discourse as a whole and is a constitutive part of its ongoing development and reinforcement. ${ }^{32}$

He goes on:

This naturalization makes the (seemingly unproblematic) vernacular landscape (of our suburb, our drive to work, our college campus) perhaps even more powerful in its disciplinary capabilities. ${ }^{33}$

\footnotetext{
${ }^{30}$ Williams, "Ideas of Nature," 68.

${ }^{31}$ Schein, "Normative Dimensions of Landscape," 201.

${ }^{32}$ Schein, "The Place of Landscape," 663.

${ }^{33}$ Ibid.
} 
For Schein, the landscape is normative because it expresses what should be.

But I also want to argue that Williams' second definition of nature—as the essential character of the nonhuman world-is also one of the ways in which landscape comes to “efface its own readability," as W.J.T. Mitchell phrases it. ${ }^{34}$ Nature is a word often taken for granted, and assertions about the fundamental truth of nature are commonplace. But these assume a coherence and stability to the nonhuman world, an idea that is often deeply problematic. Williams admits this, noting that when faced with propositions of the sort, "Nature is...," his inclination is to always complicate the assertion. But these assertions, visions of what Williams calls "a singular and essential nature, with consistent and reconcilable laws" are still often taken for granted. ${ }^{35}$ And they allow for conceptualizations of nature to appear neutral, as though they are descriptors of an essential truth rather than expressions of human meaning-making. In this way, by pulling on metaphors that suggest a kind of purity inherent in the natural world, catalogers of Detroit's ruins further the normative dimension inherent in landscape. Through suggesting that nature is a coherent entity, photographers of Detroit use metaphors of nature to obscure the contingent reality of the city's present. In short, "nature" is part of the process by which landscape "naturalizes" itself in Detroit.

\footnotetext{
${ }^{34}$ Mitchell, "Introduction," 2.

${ }^{35}$ Williams, "Ideas of Nature," 70.
} 
Sam Dennis gives voice to this capacity of natural landscapes to obscure their production in a 2006 essay. ${ }^{36}$ Dennis finds that the evidence of the elaborate labor systems that allowed for rice production in the pre-Civil War Coastal South no longer exist in the landscape unless one is looking from above. In this instance, it is precisely the capacity of natural systems to disguise human modification that allows for this erasure to take place. These are profoundly human-created landscapes made to seem natural, not by human intent but by decidedly natural processes. As Schein argues, "The landscape is not innocent."37 Other approaches to landscape echo this normative dimension, in particular the work of Don Mitchell. Mitchell attempts to intertwine competing imaginaries of landscape-as gaze and as materiality — through the concept of labor. For Mitchell, labor is a kind of mediation between landscape-as-representation and its actual production. As he notes, ... a landscape is a 'work' - a work of art, and worked land. But as Raymond Williams, like Cosgrove, was at pains to point out, one of the purposes of landscape is to make a scene appear unworked, to make it appear fully natural. So landscape is both a work and an erasure of work. ${ }^{38}$

For quite some time while working on this project, I struggled to connect Mitchell's work with my interest in Detroit, since much of Detroit's present landscape looks the way it does precisely due to the lack of labor. But I soon realized that this was assuming a kind of passivity inherent in decay. As Jerry Herron argues, “...neglect (doing nothing) is, in fact, an act of production; as far as postmodern Detroit is concerned, it is the act of production

\footnotetext{
${ }^{36}$ Samuel F. Dennis Jr., "Seeing Hampton Plantation: Race and Gender in a South Carolina Heritage Landscape," in Landscape and Race in the United States, ed. Richard H. Schein (New York: Routledge, 2006).

${ }^{37}$ Schein, "Normative Dimensions of Landscape," 203.

38 Mitchell, The Lie of the Land, 17.
} 
responsible for the city's present state." ${ }^{39}$ As Herron makes clear, decay is itself an active process, and the dissolution of Detroit's landscape is as much a product of labor as are Mitchell's rural California landscapes. Detroit is a product of what Marshall Berman calls "'urbicide, the murder of a city," and assuming passivity to the processes that have constructed Detroit's present landscape is part of the reason why Detroit's decline comes to be seen as natural or inevitable. ${ }^{40}$

\section{Critical Approaches to Photography}

In order to further these linkages between landscape and representation, I ultimately began to ask about the role of photography in the production of particular landscapes. Gillian Rose has undeniably done the most to bring visual analysis to the forefront of geographic inquiry and has helped make explicit the deep relationships between photographic representations and power. She compels geographers to ask questions about the ways in which "particular visualities structure certain kinds of geographical knowledges, knowledges - and thus visualities - that are always saturated with power relations." ${ }^{41}$ This is an important point, and it is crucial to keep in mind the discursive and subsequently political effects of representation. Visual representations are not neutral. Instead, they are products of particular authors and open to particular interpretations and reinterpretations. Rose quotes Fyfe and Law, who argue:

\footnotetext{
${ }^{39}$ Herron, AfterCulture, 85.

${ }^{40}$ Marshall Berman, “Among the Ruins," New Internationalist 178 (1987), 2.

${ }^{41}$ Gillian Rose, “On the Need to Ask How, Exactly, Is Geography 'Visual'?," Antipode 35, no. 2, 213.
} 
To understand a visualization is...to enquire...into the social work that it does. It is to note its principles of inclusion and exclusion, to detect the roles that it makes available, to understand the way in which they are distributed, and to decode the hierarchies and differences that it naturalises. ${ }^{42}$

This reference to naturalization enables a commonality to be found within critical work on photography and the cultural landscape tradition. Both are means by which one reality comes to be understood as somehow normal or natural. I argue in this paper that photography is one of the ways in which Detroit's present comes to be seen as somewhat inevitable. Like landscape, it is the capacity of photographs to appear truthful that allows them to stand in as accurate records of place. But photographs are an inherently limited and mediated vision. The result is that to investigate photography is effectively to look for what is not there.

But since critical investigations into photography and power have occurred for decades, for the purpose of this paper I rely on critical accounts of photography in two distinct scholarly contexts: Postcolonial scholarship that looks at the relationship between photographs and what Edward Said called "imaginative geographies"; And literature that stresses the importance of visual images in contemporary urban development.

\section{Geographic Imaginations}

In 1977, the same year that Yi-Fu Tuan would explore the diversity of spatial imaginations in Space \& Place, Edward Said wrote:

\footnotetext{
${ }^{42}$ Gordon Fyfe and John Law, Picturing Power: Visual Depiction and Social Relations (London: Routledge, 1998)
} in Gillian Rose, "On the Need," 213. 
...this universal practice of designating in one's mind a familiar space which is 'ours' and an unfamiliar space beyond 'ours' which is 'theirs' is a way of making geographical distinctions that can be entirely arbitrary.",43

Said would refer to these as "Imaginative Geographies," an idea that would both animate much of Said's project but also the work of many in Geography. ${ }^{44}$ Imaginative Geographies are constructions and representations, ways of familiarizing ourselves with others while also differentiating ourselves. And as Derek Gregory points out, these geographies are not just representations. Instead, "Imaginative geographies are discursive formations, tense constellations of power, knowledge and spatiality, that are centred on 'here' and projected towards 'there." ${ }^{, 45}$ In this framing, discourse and representation are intimately tied to the workings of power. As Said famously and eloquently put it in 1979:

Just as none of us is outside or beyond geography, none of us is completely free from the struggle over geography. That struggle is complex and interesting because it is not only about soldiers and cannons but also about ideas and forms, about images and beginnings. ${ }^{46}$

Yet Said, a literary critic, was largely silent on how visual, rather than literary representations, help to construct these imaginaries of the other. As a result, scholars from Geography and beyond have found ways of thinking about how photographs help to construct particular imperial imaginations. These scholars have expanded and complicated Said's project, analyzing the complex interplay between spatial representation and lived

\footnotetext{
${ }^{43}$ Edward W. Said, Orientalism (New York: Vintage Books, 1979), 54.

${ }^{44}$ Edward Said, Orientalism; Edward Said, Culture and Imperialism (New York: Knopf, 1993); Derek Gregory, "Between the Book and the Lamp"; Derek Gregory, The Colonial Present: Afghanistan, Palestine, Iraq (Malden, MA: Blackwell Publishing, 2004); Derek Gregory, "Edward Said's Imaginative Geographies," in Thinking Space, ed. Mike Crang and Nigel Thrift (London: Routledge, 2000), 302-348.

${ }^{45}$ Gregory "Between the Book and the Lamp," 29.

${ }^{46}$ Said, Culture and Imperialism, 7.
} 
reality. ${ }^{47}$ It should be noted as well that postcolonial scholars have critiqued the somewhat monolithic image of colonialism articulated by Said in favor of conceptions of (post)coloniality that focus on fracture, unevenness, and plurality. Gregory is representative of this critical engagement with Said, and he uses accounts of travelers to Egypt in 1849 and 1850 to demonstrate the ways in which colonialism was never completely monolithic or homogenous. ${ }^{48}$ In describing the journeys of Florence Nightingale and Gustave Flaubert, Gregory examines the "uneven topographies" of gender and patriarchy that enabled them to have radically different experiences of nineteenth century Egypt.

More important for my analysis is the work of Joan Schwartz, who uses the same historical period to link photographic scholarship with postcolonial accounts of imaginative geographies. In her 1996 essay, The Geography Lesson, Schwartz argues that photographs made by travelers to Egypt in the nineteenth century altered Western perceptions in two ways: They "both denied and demonstrated change" and in doing so allowed for impressions of Egypt to become "fixed in the collective consciousness of Western audiences" where they "persisted long after change on the ground undermined the timeliness of portrayal"; And they functioned as "pre-texts," which "filtered reality and established the itineraries of travel" as

\footnotetext{
${ }^{47}$ See Derek Gregory, "Emperors of the Gaze: Photographic Practices and Productions of Space in Egypt, 18391914," in Picturing Place: Photography and the Geographical Imagination, ed. Joan Schwartz and James Ryan (London: I.B. Tauris, 2003), 195-225; James R. Ryan, Picturing Empire: Photography and the Visualization of the British Empire (London: Reaktion Books, 1997); Joan Schwartz, "The Geography Lesson: Photographs and the Construction of Imaginative Geographies," Journal of Historical Geography 22, no. 1 (1996), 16-45; Joan Schwartz and James Ryan, Picturing Place: Photography and the Geographical Imagination, ed. Joan Schwartz and James Ryan (London: I.B. Tauris, 2003).

${ }^{48}$ Gregory, "Between the Book and the Lamp."
} 
well as often served as a "surrogate for travel."49 These arguments will be clear to anyone who has ever used a tour guide, but what is engaging about Schwartz's analysis is the ways in which photographers were active agents in the production of imaginative geographies. Visits to Egypt were thus "acts of confirmation" of pre-travel imaginaries. ${ }^{50}$ The same can presumably be said for many visits to Detroit in search of the city's ruins.

\section{Image and Urban Redevelopment}

A secondary way of thinking about images and power has to do the relationship between representation and urban redevelopment. Images and representations are inherently limiting, and privilege certain visualities while occluding others. Images made of Detroit's ruins - which focus entirely on Detroit's limitations — stress a particular vision of the city, one that conflicts with the images made by urban boosters and developers interested in selling the city's perks. By bringing attention to Detroit's faults, ruin documenters are highlighting a part of the city that both residents and politicians are trying to downplay. Finding a way to highlight the city without either glossing over its problems or reveling in its decay is one of the central questions of this project. In order to engage with it, it was important to think about the role of image and representation in urban rebranding strategies. This is especially important given Detroit's recent attempts at cleaning up its downtown as part of a redevelopment strategy focused on bringing tourists into the city to see sporting events, gamble at the newly built casinos, and spend time at the city's riverfront. These

\footnotetext{
${ }^{49}$ Schwartz, "The Geography Lesson," 31.

${ }^{50}$ Ibid., 33.
} 
strategies are fairly commonplace and arguably reflect broader trends in urban development.

They are not unique to Detroit.

In other declining cities, constructing a particular image has become a central

component of revitalization strategies. As Robert Beauregard argues:

From Sydney to Seattle, from Johannesburg to Helsinki, civic elites have become obsessed with the image that their cities project to the world. At a time when cities must compete with each other for investors, tourists, tax revenues, and middle-class residents, how the city is perceived is considered of paramount importance. Consequently, civic boosters commission a variety of images: of gleaming office towers, of lively streets bordered by cafes, of housing whose residents can gaze out on both snow-capped mountains and multi-peaked skylines, of sailboats nestled in downtown marinas, and of couples and families strolling along riverfront parks. ${ }^{51}$

Similarly, Pagano \& Bowman argue that images are a crucial component in urban redevelopment. In their case study of 10 American cities, as diverse as Huntsville, AL and Duluth, MN, they find a series of related projects aimed at image enhancement as a means of redevelopment. They conclude:

Local economic development is commonly thought of in terms of job growth and changes in the tax base. And while it certainly contains elements of both, it is at the same time something else. Image, a concept difficult to isolate and quantify, plays a central role in economic development. A city's image is the backdrop against which development occurs; and image creation is frequently a goal of the economic development process...Despite the intangibility of image, it remains critical to local economic development. ${ }^{52}$

The waterfront redevelopment of Baltimore in the early 1980s is a clear demonstration of this style of development by way of tourism and subsequent gentrification.

\footnotetext{
${ }^{51}$ Robert Beauregard, "Images of Renewal and Decline," (paper presented at "Beyond the Post-Industrial City," Rutgers University, Camden, NJ, November 18, 2005).

52 Michael A. Pagano and Ann O'M. Bowman, Cityscapes and Capital: The Politics of Urban Development (Baltimore: The Johns Hopkins University Press, 1997), 67.
} 
David Harvey argues that while the ultimate effect on Baltimore's homelessness, poverty and educational provision was marginal, Baltimore's "architecture of spectacle, with its sense of surface glitter and transitory participatory pleasure, of display and ephemerality, of jouissance" was nonetheless seen as successful." ${ }^{, 53}$

For Harvey, this is part of what he has called the shift from managerialism to entrepreneurialism in urban governance. As he argues:

Put simply, the 'managerial' approach so typical of the 1960s has steadily given way to initiatory and 'entrepreneurial' forms of action in the 1970s and 1980s. In recent years in particular, there seems to be a general consensus emerging throughout the advanced capitalist world that positive benefits are to be had by cities taking an entrepreneurial stance to economic development. What is remarkable, is that this consensus seems to hold across national boundaries and even across political parties and ideologies. ${ }^{54}$

Images are thus a crucial component of an increasingly uneven and increasingly precarious model of urban development. Dennis Judd refers to the dangers of tourist development when he envisions the tourist bubble, a development that both simplifies the complexity of a city into a marketable image while also constructing an area of consumption and wealth that is often segregated from the rest of the city. ${ }^{55}$ Convention centers, sports franchises, casinos and outdoor malls all help to lure tourist dollars into cash-strapped urban centers, but they do so at the mercy of tax breaks and increasing inequality. Howard Gillette,

\footnotetext{
${ }^{53}$ David Harvey, The Condition of Postmodernity: An Enquiry into the Origins of Cultural Change (Cambridge, MA: Blackwell Publishing, 1990), 91.

${ }^{54}$ David Harvey, "From Managerialism to Entrepreneurialism: The Transformation in Urban Governance in Late Capitalism," Geografiska Annaler B 71 (1989): 4. See also Helga Leitner and Eric Sheppard, "Economic Uncertainty: Inter-Urban Competition and the Efficacy of Entrepreneurialism" in The Entrepreneurial City: Geographies of Politics, Regime and Representation, ed. Tim Hall and Peter Hubbard (Chichester: John Wiley \& Sons, 1998).

${ }^{55}$ Dennis R. Judd, “Constructing the Tourist Bubble" in The Tourist City, ed. Dennis R. Judd and Susan S. Fainstein (New Haven: Yale University Press, 1999).
} 
Jr. articulates this dilemma in his book Camden after the Fall. ${ }^{56}$ In it, he traces the ways in which Camden, NJ's politicians pursued redevelopment in largely representational terms by focusing on the waterfront and entertainment sectors and stressing the city's positive features. In contrast, Gillette, Jr. juxtaposes the profound structural inequalities, high taxes and massive poverty that resulted in police officers lining the edge of the waterfront during events to insure that visitors did not stray too far into Camden itself. ${ }^{57}$ He details the often impossible tasks faced by community organizations and activists, for whom neighborhood redevelopment is always one step behind blight and crime.

In the case of Detroit, where the scale of the city's decline is almost staggering, urban development has largely followed the model put forth by Harvey. The result is that downtown neighborhoods feel decidedly urban and safe, in contrast to what many expect to find in Detroit. Similarly, neighborhoods like Corktown and Mexicantown—places that many Detroiters refer to as "intact"- - are reminiscent of other Midwestern industrial cities. But other neighborhoods are not as successful, and the extent of the city's vacancy can be profoundly off putting. The question is how effective has this model of cosmetic redevelopment been in bringing jobs and capital into neighborhoods of the city that do not connect with the downtown. And the bigger and more unanswerable question is how to imagine approaches to redevelopment that stress local job creation and local involvement, rather than just tourist development.

\footnotetext{
${ }^{56}$ Howard Gillette, Jr., Camden After the Fall (Philadelphia: University of Pennsylvania Press, 2005).

${ }^{57}$ Ibid., 144.
} 
For the smaller scale purposes of this thesis, I focus on the role of images in rebranding efforts as a way of highlighting the toxic and contested terrain that photographers enter into when they publish photographs of the city. Highlighting Detroit's faults is an intellectual tradition with a long genealogy, but to do so is to engage with the complicated politics of representation associated with the city's efforts at redevelopment. Constructing exploitative images of the city's ruins irks Detroit residents and represents a challenge to urban boosters interested in rebranding the city.

\section{Methodology}

The capacity of representations to influence how places are perceived and experienced is a largely open ended question. Despite scrutiny from geographers and social scientists, the actual mechanics of translating image into place are often arbitrary and unarticulated. My research methods for this project were subsequently open-ended and qualitative, and I pursued a mixed methodological strategy. I focused on representations made of the city found primarily online and in print, and assembled a database of images and accounts of the city. As that became overwhelming, I began to focus primarily on image sets and stories focused on the city's ruins. Throughout my research, I probed for inclusions and exclusions made of the city, and noted repetitions and predetermined routes.

My primary source of data was photographs made of the city of Detroit, many of which were juxtaposed with texts and published in magazines (both print and online), blogs, informal tourist guides, personal and professional websites, and personal photography sites. I concentrated on tones and moods, as well as geographic location and framing. With 
photographs, I was primarily interested in absences, invisibilities and stylistic or thematic similarities. One danger of this kind of analysis is how to determine audiences and authors, and how to properly connect representations to places. Through the theoretical lens of imaginative geographies and the Cultural Landscape tradition, I looked at representations as not necessarily monolithic but instead evocative of contradictory and ambiguous cultural imaginings. In order to try and step beyond my own positionality, I analyzed responses to the images written by online commentators. Online comments are inherently hard to do use as data, due to their lack of geographic or demographic particularity. Nevertheless, in the case of Detroit images, I used them as a way of assessing why and how these photographs were reaching such expansive audiences. Anecdotal and testimonial evidence suggests that these images are popular, and so online comments were seen as a way of assessing why commentators were being drawn to them. ${ }^{58}$ They are incomplete and partial, but are a way of assessing how consumers are responding to these images in their own words. In addition to online comments, I used newspaper articles and editorials as a way of assessing how a broader cross section of Detroiters was responding to images made of the city.

Many images made of Detroit are part of mixed media documents, and so I focused on both visual and textual representations of the city. Much of the data for this project was

\footnotetext{
${ }^{58}$ Journalist Thomas Morton mentions a photo essay by James Griffioen of an abandoned Detroit public school that "tripled our website's traffic for nearly a week." In Thomas Morton, "Something, Something, Something, Detroit," Vice, August, 2009. Similarly, when describing a set of photographs made of Detroit's "feral houses," Griffioen himself notes, "Nothing I have ever done has resonated as much as the photos of what I called "feral houses" last summer. A quickly dashed-off blog post written while children tugged at my sleeves ended up capturing the attention of hundreds of thousands of people around the world and I still get hundreds of hits to that post every day. Even Alan Weisman, author ofThe World Without Us, e-mailed me about them." Sweet Juniper blog. http://www.sweet-juniper.com/2009/07/feral-houses.html (accessed October 1, 2009).
} 
taken from newspapers and other media outlets. Robert Beauregard is a model for how to engage with the city through written representations and his 1993 book, Voices of Decline, details the ways in which public discourse influences urban policy. But he also argues:

All representations are indeterminate; their meanings depend not only on strategic juxtapositions with other understandings but also on shifting empirical references. The discourse is disorderly and thematically unstable; it is a collective representation of shared and contested meanings. ${ }^{59}$

The result is that Beauregard, like Rose, suggests that representation is contested and fragmentary but ultimately still influential. He uses this as a pretext for combing through media representations of urban decline. In a similar vein, I performed textual analyses of various professional and amateur representations of Detroit's ruins. I checked the Detroit Free Press and the Detroit News daily and typically focused on articles that dealt with historic preservation and architecture. In addition to local news sources, I relied on national newspapers as well as periodic articles from international news sites. Newspapers were a means of establishing a partial sense of how Detroiters were responding to images made of their home. Through cataloging and ordering, I gained a sense for how the city was being represented, and how representations of decline fed into political decision-making. There are a variety of different ways in which Detroit is constructed, but my interest was in assessing the prominence and political dimensions of a particular image of the city. I attempted to ask

${ }^{59}$ Beauregard, Voices of Decline, 22. 
who and what was being represented, and how these representations bled into actual redevelopment efforts. ${ }^{60}$

In order to personalize my research, I also performed qualitative interviews with six Detroiters involved in Historic Preservation either as employees of the city or activists. These interviews were designed as a way of gauging responses to images made of the city as well as to get a better sense for Detroit in broad strokes. Interviews provided a way to ground and contextualize the imaginative depictions that characterize the city, and helped to form a bridge between a largely national geographic imagination and more localized politics. Interview subjects were intermediaries between representation and morphology, in a way, and they gave me a great deal of insight into the nature of everyday life in the city. Too much urban history writes of decline and decay as thought these are inevitable and mundane occurrences, but interview participants articulated the many ways in which decline is combated.

And finally, since this is ultimately a paper about landscape, I spent quite a bit of time in the city of Detroit walking, driving, and conversing with Detroiters. While this rarely yielded much in the way of concrete knowledge and analysis, it nevertheless allowed me to formulate questions and construct an admittedly personal vision of the city that is a product of my own positionality as an outsider. Visits to the city were a way of constructing my own

\footnotetext{
${ }^{60}$ It should be noted here that in recent years, geographers have backed away from questions of representation in favor of approaches that highlight bodily and experiential methodologies and approaches. For the purposes of this research, representation is considered nevertheless to be part of how present day actors and subjects navigate their lives. Non-representational theorists hold open the possibility of engaging with the profundity of affective encounters, but to ignore the ways in which our own lives are mediated by the representations that surround us seems needlessly limiting at times.
} 
imaginary of the city in opposition to the image often conferred on it. I could not have written this paper without the insight given to me by actual bodily engagement with the pathways and pyschogeographies of the city. Gaining a sense for its complicated truths was a product of being open to what the city had to offer. 


\section{Chapter Three: Envisioning Detroit: Ruin Imaginaries, the Michigan Central Station, and the Politics of Representation}

Detroit is no stranger to representation. In starting his book AfterCulture: Detroit and

the Humiliation of History, Jerry Herron notes:

This is a book about Detroit; it is also, unavoidably, a book about representation because Detroit is the most representative city in America. Detroit used to stand for success, and now it stands for failure. In that sense, the city is not just a physical location; it is also a project, a projection of imaginary fears and desires. ${ }^{61}$

Since Detroit's high profile decline over the last half century, the city that has often functioned as both a dystopian image of a probable urban future and an isolated vision of urban decline. Detroit is both other but also bellwether of things to come. Herron and other Detroit scholars reference newscaster Diane Sawyer's 1990 visit to Detroit in which she opened with:

Our first story is not a story about a city...It's a story about some Americans who may be sending a kind of warning to the rest of us...Detroit, once a symbol of U.S. competitive vitality, and some say still a symbol: a symbol of the future, the first urban domino to fall.," 2

In an updated time and context, John Reed of the Financial Times repeats this

cautionary lesson in a March 2009 article: “Detroit is no longer the nation's worst-case scenario, but on its leading edge, the proverbial canary in the coal mine." Pointing to the

\footnotetext{
${ }^{61}$ Jerry Herron, AfterCulture: Detroit and the Humiliation of History (Detroit: Wayne State University Press, 1993), 9.

${ }^{62}$ In Herron, AfterCulture, 15.
} 
current recession, Reed quotes blogger Peter De Lorenzo, who states "It's like the rest of the country is getting to where Detroit has been." 63

But Detroit is also somewhat antithetical. In light of the current rehabilitation and gentrification of cities like New York and Pittsburgh, Detroit remains in popular imagination as a stubborn dinosaur, incapable of transcending its own social ills in order to move forward in some version of capitalist urban development. It is a thoroughly othered city. As Herron argues: "Its representations in the media stand for what everyone else fears and wants to be different from: a singular, cautionary disaster from which people elsewhere imagine they still have time to retreat." ${ }^{\prime 64}$ Events like the yearly Devil's Night, in which Detroiters torch abandoned homes on Halloween weekend, point to an image of Detroit where the city's decline comes to function as a mirror of everything the rest of the country is not: "black and violent, sick, abandoned, poor," as Herron puts it. ${ }^{65}$ Ze'ev Chafets' 1991 search for Detroit in Devil's Night is the perfect expression of this particular mythology, mirrored in contemporary films like Paul Verhoeven's Robocop. ${ }^{66}$

But since the 1990s, narratives of Detroit seem to have shifted. Detroit is now more often conceptualized in terms of emptiness and a kind of mournful longing for the past, part of a recent explosion of images made of Detroit's so-called ruins. In this chapter I outline a brief history of Detroit's ruin imaginary that focuses on the tension between aesthetic appreciation and the political responses suggested by decay. I start by focusing on a set of

\footnotetext{
63 John Reed, "The Travails of Detroit," Financial Times, March 6, 2009.

${ }^{64}$ Herron, AfterCulture, 100.

65 Ibid., 15.

${ }^{66}$ Ze'ev Chafets, Devil's Night: And Other True Tales of Detroit (New York: Random House, 1990).
} 
websites and projects that document Detroit's supposedly picturesque beauty. After outlining the general trends, I focus on a particular site-The Michigan Central Station-as a way of analyzing how these images feed back into decisions made in the city itself. I argue that controversies associated with the site's impending demolition not only demonstrate the ways in which images circulate back in the city, but they also provide evidence for how Detroiters are able to resist the image conferred on them through the symbolic language of demolition. In this way, demolitions of prominent buildings are not just understandable but potentially positive as well, contrary to the arguments made by historic preservationists. I conclude by looking at the Heidelberg Project, an art installation in Detroit. I use the project as a way of thinking about representations that neither depopulate the city nor ignore its pressing issues. Throughout, I conceive of images not strictly as representations but also as historic and material objects, capable of influencing behavior through their circulation, publication, and consumption.

\section{The Industry of Decay}

Images of Detroit's decaying buildings and crumbling infrastructure have been a prominent part of representations made of the city over the past two decades, but their popularity has exploded in the past three years. In journalist accounts and amateur websites, blogs and photography portfolios, Detroit has become hip. In 2008 and 2009, there were two consecutive photo essays in Time Magazine ${ }^{67}$, one fifty image series in Life.com, a photo

\footnotetext{
67 "The Remains of Detroit," Time.com, http://www.time.com/time/photogallery/0,29307,1864272_1810098,00.html; “Detroit's Horrible, Beautiful
} 
essay put together by Witold Rybczynski on Slate. $\operatorname{com}^{68}$, at least three tour guides of the city's decaying beauty published online and in print ${ }^{69}$, and hundreds of flickr pages, blogs, additional photo essays, and online photography portfolios dedicated to Detroit's ruins (See Figures 5, 6, 7). More unique examples include the work by white supremacists to document how Detroit's ruins demonstrate white racial superiority, ${ }^{70}$ and documentation by urban explorer groups found online. In 2010, two books on Detroit's ruins are in print: Yves Marchand and Romain Meffre's American Ruins and Andrew Moore's Detroit Disassembled. ${ }^{71}$ All of these projects share an interest and passion for examining Detroit's crumbling infrastructure, its overgrown houses, and its empty skyscrapers.

Despite their moments of stylistic distinction, these images suggest a depopulated city, one passed over by time but not yet historic. Instead, representations of Detroit's ruins suggest a strange mythic space that is neither historic nor present. This is often a thoroughly aestheticized space, in which Detroiter's homes are seen as emblematic of the beauties of

Decline: Two French photographers immortalize the remains of the motor city on film," Time.com, http://www.time.com/time/photogallery/0,29307,1882089,00.html (accessed April 15, 2009).

${ }^{68}$ Witold Rybczynski, "Detroit's Beautiful Ruins," Slate.com, http://www.slate.com/id/2213696/slideshow/2213979/entry/2213981/fs/0// (accessed January 15 2010).

69 Brian Parks, "Going to Detroit," The New York Times, August 28, 2005; "Detroit Design Guide," Design*Sponge, http://www.designspongeonline.com/2008/01/detroit-design-guide.html (accessed June 2009); Jonathan Mahalak, "Wild wild Midwest," Chicago Reader, May 14, 2009;

${ }^{70}$ The website White History ("The Ruins of Detroit," White History, http://www.whitehistory.com/hwrdet $4 \mathrm{a} . \mathrm{htm}$ ) articulates this position. In more detail, George Steinmetz details the proliferation of Detroit images on white supremacist website Stormfront and quotes a Macombe County punk band named the "Angry Aryans." In Steinmetz, "Harrowed Landscapes": 219; See also Rebecca Solnit, "Detroit Arcadia: Exploring the Post-American Landscape," Harper's Magazine 315 (July 2007): 65-73.

${ }^{71}$ Andrew Moore, Detroit Disassembled (Akron, Ohio : Akron Art Museum, 2010); Yves Marchard and Romain Meffre, The Ruins of Detroit (London: Steidl, forthcoming). 
dereliction and decay . As one journalist for Seattle alternative newspaper The Stranger noted in a May 25, 2010 article:

The best part of living in Detroit is the ruins. The whole place is one giant urban-ruins park. Though it's sad and broken and abandoned, there is art everywhere. It's beautiful. ${ }^{72}$

Arguably the most iconic and long-standing of Detroit's ruin documentation projects is Lowell Boileau's The Fabulous Ruins of Detroit. The website, founded in 1997, is designed as a tour of the city that celebrates its history while asking questions about how it came to look the way it does. The opening page compares Detroit to Zimbabwe, Ephesus, El Tajin, Athens, and Rome, before introducing the website:

Now, as for centuries, tourists behold those ruins with awe and wonder. Yet today, a vast and history laden ruin site passes unnoticed, even despised, into oblivion. Come, travel with me, as I guide you on a tour through the fabulous and vanishing ruins of my beloved Detroit. ${ }^{73}$

The website is designed as a virtual tour of the city, and visitors can click through a series of tours arranged around different themes. The images feel more like documentary photographs than gallery presentations. People are occasionally present in the images, and all the photographs are in color. In addition to the photographs made of Detroit's ruins, Boileau has a virtual tour called "Detroit Rises" that highlights some of the recent successes in the city. The website also hosts the DetroitYES! message boards, which are a space for metro area enthusiasts to talk about the city.

\footnotetext{
${ }^{72}$ Kelly O, "Things I Remember About Detroit: Five Years of Abandoned Factories, Talking Cats, and Cars on Fire," The Stranger, May 25, 2010.

${ }^{73}$ The Fabulous Ruins of Detroit, http://detroityes.com/home.htm.
} 
There is a somewhat unsettling simplicity to Boileau's images. Unlike the overly moody photographs that make up many Detroit representations, Boileau's are shot in the middle of the day and often feature passing motorists and pedestrians in the frame. Each image is tied to a historic narrative or anecdote, and the vision is fairly comprehensive, covering much of the city but focusing primarily on industrial and downtown icons. While it is hard to quantify, the site appears to be enormously popular, and in 2006, Boileau indicated that he received about two million visits per year. ${ }^{74}$ In 2007 , he apparently received over three million visits. ${ }^{75}$ The site has continued to grow as well.

Boileau's interest in the city is both political and aesthetic, and he illuminates the tension between repulsion and attraction that characterizes many "ruingazers," to reference George Steinmetz again. Boileau is interested in the aesthetics of decay, and he notes, "What really attracts me to these buildings is their visual presence and immensity. They are simply awesome in their deliquentness, and the artist inside me stands in awe." ${ }^{, 76}$ Yet his project is also conceived as a way of turning the city around and celebrating its unique charms. On his website, he argues:

A city does not stand still in time. Its story is written every day. With the Fabulous Ruins of Detroit tour as a framework and guide, Detroit Mon Amour moves forward with the flow of time to explore the phenomenon of the International Metropolis of Detroit in depth and detail from 1999 through 2006. The following journeys meander throughout the city and the years, up to

\footnotetext{
${ }^{74}$ Amy Lange, "eCommunity: Detroit YES' Lowell Boileau," Real Detroit Weekly, August 9, 2006.

${ }^{75}$ Lowell Boileau, “The DetroitYES! Project," http://www.detroityes.com/0aboutthissite.htm (accessed February 15, 2009).

${ }^{76}$ Jason Chervokas and Tom Watson, "Digital Monuments to the Urban Past," New York Times, March 1, 1998.
} 
the present moving blending with the audience driven forums. In their segmented totality they search for the heart and meaning of Detroit. ${ }^{77}$

Boileau — as the quintessential example of a suburban Detroiter with a passion for the city—is representative of one of the typologies George Steinmetz constructs. In his 2008 article, Steinmetz argues that most Detroit ruingazers hail from the nearby suburbs and maintain a somewhat precarious relationship with the city. ${ }^{78}$ Many were once Detroiters, or are the children of ex-Detroiters, and their relationship to the city is framed by loss and racial animosity. For Steinmetz, these virtual tourists mourn the city but leave it decidedly in the past, preferring to engage in nostalgic remembrance rather than active engagement. Letters to Boileau that he publishes on his website gesture at this nostalgic dimension, and many express the sense that Detroit's ruins are a kind of violence. But Boileau is not interested in resigning the city to a historical past, and much of his project is about engaging with the city's present. The message boards attached to the site, which premiered in 2001, allow metro area residents and enthusiasts to mourn the places of their childhood while engaging in conversation about the city's future. And while I am wary of much of the politics espoused by DetroitYES! posters, the site nevertheless presents a flawed and skewed vision of the city that is worthy of commending. Boileau's site serves a particularly localized function for many of its visitors, and it is a space full of promise.

But thinking about Detroit's ruins only in terms of localized nostalgia misses much of the story. In recent years, Detroit's ruination has begun to attract visitors and documenters

\footnotetext{
${ }^{77}$ Lowell Boileau, “Tour Detroit," http://www.detroityes.com/0tourdetroit.htm (accessed Feburary 15, 2009).

${ }^{78}$ Stenimetz, Harrowed Landscapes.
} 
from much further afield. A set of articles published by Time gesture at some of the emergent ruin imaginaries of Detroit that stretch far beyond the city itself. Time's engagement with Detroit began as a series of articles, but has since morphed into a broader expose complete with a new press office in the city. The first article, published in December 2008, is entitled The Remains of Detroit. ${ }^{79}$ It arguably articulates the most representative set of current images of the city and I used it to introduce this paper. Its eleven images feature three shots of the Michigan Central Station, six images of abandoned auto plants, one shot of houses being overtaken by nature, and one shot of the Michigan Theater converted to a parking garage, a site used in a variety of sources including Detroit-based musician Eminem's film 8 Mile ${ }^{80}$ In the eleven images, the only indicators of people are a car, discarded mattresses used by the homeless, and graffiti. One image — entitled Former Housing Plots-is especially eerie. Shot in winter, the image suggests a horror movie, as one car drives down a deserted street in a scene reminiscent of rural decline. The image is foregrounded by totally empty lots—presumably arson sites—and the muted colors and dead trees convey a feeling of dread. This is the one image in Hemmerle's series that features a person, but it is only in the form of a vehicle driving menacingly down the street. The image is juxtaposed with a

\footnotetext{
79 "The Remains of Detroit," Time.com, http://www.time.com/time/photogallery/0,29307,1864272_1810098,00.html (accessed December 15, 2008). 80 In a recent article, Jerry Herron argues that Eminem's climactic performance in the Michigan Theater parking deck is a kind of repopulation of the space. In Jerry Herron, "Borderland/Borderama/Detroit: Part 3," The Design Observer Group, July 8, 2010.
} 
quote from Hemmerle, who notes that "On many occasions, I had the feeling I was working in a postapocalyptic environment." 81

A second set of images, by photographers Yves Marchand and Romain Meffre is entitled Detroit's Beautiful, Horrible Decline. ${ }^{82}$ Marchand and Meffre cover a bit more ground, and their website, linked to in the photo series, features even more shots of Detroit's decaying buildings. ${ }^{83}$ Many of these photographs have presumably been republished in their 2010 book, American Ruins, but copies of it are not yet available as of August 2010.

Alongside an image of the Depot and the Packard Plant, repeat sites from Hemmerle's series, the photographers document a variety of decaying schools and apartment complexes. The photographs are all in color, but feature the famed Detroit haze, which renders them all fairly ominous in nature. People are absent in these images and the images are presented alongside brief snippets of text that typically note the construction and demolition dates of the buildings. In addition to the sites previously mentioned, the photographers feature one shot of the William Livingstone Mansion, affectionately known as "Slumpy” by Detroit's ruin voyeurs. The house was demolished in 2007.

A February 5, 2010 photo series in Life follows a similar model. Entitled Ragged Glory: Detroit's Geography of Ruin and Hope, photographer Keith Marlowe covers more

\footnotetext{
81 "The Remains of Detroit," Time.com, http://www.time.com/time/photogallery/0,29307,1864272_1810098,00.html (accessed December 15, 2008). 82 "Detroit's Horrible, Beautiful Decline: Two French photographers immortalize the remains of the motor city on film," Time.com, http://www.time.com/time/photogallery/0,29307,1882089,00.html (accessed April 15, 2009).

${ }^{83}$ Yves Marchand \& Romain Meffre, "The remains of Detroit," Yves Marchand \& Romain Meffre Photography, http://www.marchandmeffre.com/detroit/index.html (accessed April 15, 2009).
} 
ground than previous artists, but focuses on iconic Detroit ruins: The Brewster Projects, one time home of Diana Ross, The Michigan Central Station, The David Broderick Tower, the almost required shot of the Michigan Theater converted into a parking garage, and Detroit's iconic abandoned zoo, muse to many Detroit documenters. ${ }^{84}$ In one shot, Marlowe resists the urge to call the entirety of downtown Detroit a ruin when he notes that his view is of the rumored new Red Wings arena. This part of downtown is an area that gives off the impression of rather staggering devastation but is largely owned by a prominent local developer and is awaiting construction. In this moment, Marlowe gestures at both the present and the future in a way that is subtle yet effective.

Marlowe's series is arguably designed as a corrective to what many journalists refer to as "Ruins Porn." His editors even make this argument, noting in their introduction to the piece:

Marlowe's task, of course, was not simply to photograph desolation. Wellaware of the risks facing anyone hoping to chronicle the fall of a great metropolis, he worked to avoid being just another purveyor of what Detroiters have come to call "ruins porn." For the citizens who still proudly -- even defiantly -- call Detroit home, the city is not some vast relic. It's not a mausoleum. It's where they work (if they have jobs); where they send their kids to school (if they can't afford, or have chosen against, a private alternative); where they go out to eat and see ball games and go to church. Marlowe's photographs, then, are not so much about the "ruins" as about the swagger, certainty, and nerve of a city capable of creating such glories in the first place, and the hope that old-school Detroit audacity has not entirely vanished. ${ }^{85}$

\footnotetext{
84 “Detroit: Still Life," Life.com, Feburary 5, 2010, http://www.life.com/image/ugc1029432/in-gallery/36682 (accessed April 2010).

${ }^{85}$ Ibid.
} 
Yet the photographs do not echo this promise. Instead, despite the moments of nuance, Marlowe follows the same tourist routes and covers nearly the exact same ground as other photographers. This includes covering the same sites as well as using similar themes, including the oft-repeated shot of a sapling growing inside of an abandoned building, an image designed to suggest a positive future. Despite the editors' promise to not just create more "ruins porn," Marlowe does precisely that. He converts a complicated city into a set of easily reproducible images.

As Gillian Rose has argued, absences in photographs are often as important to note as what is included. It is easy to find absences in images made of Detroit over the past two years. One absence is obviously the city itself: In the three photography series previously mentioned, the photographers follow almost uncannily similar routes. All include photographs of the train station, all include photographs of the Packard and Fisher plants, and specific photographs are almost identical. The result is that one gets a deep sense of déjà vu when looking at images made of the city, as Detroit photographers follow prescribed routes and borrow from standard conventions and narratives. These are images of a city that serve to continually reinforce one particular story of the city. And while geographic particularity is not reason enough to dismiss these representations as problematic, the limited scope and scale of this collection is largely representative of how Detroit's cataloguers locate the city. It is the abandoned plants and the decaying train station that have ultimately come to define it, rather than the everyday sites which define most Detroiters' lives. 
In a hilarious send-up of "ruins porn," Thomas Morton of hipster documentarians

Vice Magazine gives voice to the reproducibility of this image of Detroit:

The Michigan Central Depot is a hulking, bombed-out turn-of-the-century train station that's constantly used by papers and magazines as a symbol of the city's rot. The only problem is, aside from looking the part, it doesn't have too much to do with any of the issues it usually gets plastered above. It's owned by a billionaire trucking tycoon, not the bankrupt city; it was shut down back in the 80 s, not because of any of the recent crap. Nevertheless, back in December when the auto executives were in front of Congress, Time ran a photo essay to go with the story, opening and closing with shots of the terminal. Three months later they ran another spread about the city's decay, although this time they limited the depot shots to one.

In addition to being a faulty visual metaphor, the train station has also been completely shot to death. For a derelict structure, it's kind of a happening spot. Each time I passed by I saw another group of kids with camera bags scoping out the gate. When I finally ducked in to check it out for myself, I had to wait for a lady artist from Buffalo, New York, whose shtick is taking nude portraits of herself in abandoned buildings, to put her clothes back on. Afterward I was interrupted by a musician named Deity who was making a video on the roof. ${ }^{86}$

My own visits to the train station were met with a similar degree of overcrowding, as tourists cycled through to document the site. Recently, I encountered an African-American family having a barbecue in the park in front of the train station, which gave the neighborhood a decidedly lived-in feel. But everyday occurrences like these are easily cropped out when documenting ruins, and most images of the train station neglect the fact that directly behind it is a thriving upscale barbecue restaurant as well as the generally intact neighborhood of Corktown. Like all images, ones made of the train station are about particular visions and particular moods. Morton quotes a local photographer and blogger, James Griffioen, who gives tongue-in-cheek tips on how to crop out obtrusively busy buildings in order to

${ }^{86}$ Morton, "Something, Something, Something, Detroit." 
represent the city's urban prairie. Griffioen also smartly notes that, like the depot, many empty landscapes in the city are products of particular development deals gone bad. ${ }^{87}$ The ruins of Detroit are not necessarily the result of the "ravages of time" but the more mundane realities of high property taxes and limited capital.

One of the dangers of "ruins porn" is not just that it obscures the city but also that it celebrates decline and poverty. Subsequently, a fair bit of controversy has been generated by the popularity of Detroit's ruins, and journalists and critics have attempted to interrogate the voyeuristic dimension implicit in many images made of the city. ${ }^{88}$ But assessing how to criticize the politics inherent in an aesthetic document is difficult. In one response to Andrew Moore's Detroit Disassembled, journalist Celeste Headlee attempts a solution by arguing that journalists and artists need to be held to different standards. She notes, “As far as I'm concerned, artists have the freedom to take and edit photos however they choose; photojournalists, on the other hand, do not have that right." 89 But this split-between journalism and art — feels problematic and arbitrary, and determining what is journalism and what is art is a difficult project. Photojournalists pull from artistic conventions, obviously, and descriptive sets like Marlowe's Detroit: Still Life thread the line between art and journalism. His series is presented as a virtual exhibit, but also as an accurate and detailed expose of struggling Detroit. Determining when to expect truth and when to expect aesthetic meaning is impossible.

\footnotetext{
87 Ibid.

${ }^{88}$ See Karen Dybis, “Art or Exploration?” The Detroit Blog, July 1, 2010.

${ }^{89}$ Celeste Headlee, "Is 'Ruin Porn' Art or Journalism?," The Takeaway, July 6, 2010.
} 
Furthermore, separating art from journalism assumes that people's politics are not navigated and articulated through their engagements with formal artistic practice or journalistic representation. In one image, entitled Packard Plant: Landscape, Marlowe elucidates the overlaps between political identity and landscape representation. Whether consciously or not, he seems to directly invoke the foundational American landscape work of Thomas Cole. In particular, his image suggests Cole's Course of Empire series. In the image, Marlowe substitutes the wide expanse of the Detroit's famed Packard Plant itself for the ocean found in Cole's image, Desolation. The columns of the industrial plant almost mirror the ornate column found at the foreground of Cole's image, and the water tower in the background of Packard Plant: Landscape stands as a kind of substitute Witness Mountain. And Marlowe's photographs are not unique in this aesthetic similarity to Cole, and most images made of the city in recent years at least partially invoke Cole's Desolation. Given this consistency, one can easily imagine these photographers using Detroit as a way of updating Cole's fear of human technological hubris. The similarities suggest that photographers are heeding Cole's warning against straying too far from a pastoral landscape. In this way, by pulling on landscape conventions that have a long genealogy, these photographers complicate any capacity to separate journalism and art.

Additionally, landscape imagery has long been tied into questions of American national identity, and referencing landscape conventions ties photographers directly into questions of power and appropriation. As Stephen Daniels notes, "Landscape imagery is not merely a reflection of, or distraction from, more pressing social, economic or political issues; 
it is often a powerful mode of knowledge and social engagement. ${ }^{90}$ In short, landscape is about power and vision, and more accurately, it is about who has the power to order and represent particular landscapes. Landscape conventions enable photographers and painters to order and naturalize the scenes they are representing. As Dennis Cosgrove argues, landscape:

... is an ideological concept. It represents a way in which certain classes of people have signified themselves and their world through their imagined relationship with nature, and through which they have underlined and communicated their own social role and that of others with respect to external nature. $^{91}$

Obviously, Marlowe, like most ruin photographers in Detroit, is operating in a radically different context, and he is not necessarily using landscape conventions to appropriate the city from above. But like most photographers documenting Detroit, he catalogs the city from afar, both metaphorically but also physically. In this, his photographs seems to echo Edward Said's declaration that, "The Orientalist surveys the Orient from above, with the aim of getting hold of the whole sprawling panorama before him. ${ }^{, 92}$ Images of Detroit follow similar conventions that not only locate the city in particular ways but also locate the city at a distance. Part of this has to do with the lack of people in the shots, but it also has to do with the ways in which Detroit is represented as a coherent landscape, capable of being read and understood by those on the outside. Marchand and Meffre's photographs, in particular, suggest a documentary feel, and their photographic method is almost surgical in

\footnotetext{
${ }^{90}$ Stephen Daniels, Fields of vision : landscape imagery and national identity in England and the United States (Cambridge: Polity Press, 1993), 8.

${ }_{91}$ Dennis E. Cosgrove, Social Formation and Symbolic Landscape (Madison, WI: The University of Wisconsin Press, 1998 [1984]).

${ }^{92}$ In Gregory, “Edward Said's Imaginative Geographies."
} 
its precision and focus. Their images are certainly aesthetic products more than they are truth claims, but the line is remarkably blurry, as the documentary quality of the images gives them the aura of truthfulness. The result is that letting artists off the hook for being artists rather than journalists becomes increasingly difficult especially given the history of landscape painting as a political practice.

Admittedly, Andrew Moore comes the closest to both presenting a more comprehensive image of the city—complete with residents! — while also raising questions that stretch beyond Detroit. But his images still order the city and suggest coherency, whereas I would argue that what is needed in Detroit is actually displacement and fracture. Too often the city is made to speak for a political project, but this reifies one particular narrative. It feels disingenuous to construct parallels between Orientalist imaginations and Detroit representations, but it is hard to look at images made of Detroit without yearning for a post-colonial representational space that rejects the attempts at closure implicit in many Detroit imaginaries. What is needed is the narrative style suggested by Edward Said in After the Last Sky:

Our characteristic mode, then, is not a narrative, in which scenes take place seriatim, but rather broken narratives, fragmentary compositions, and selfconsciously staged testimonials, in which the narrative voice keeps stumbling over itself, its obligations, and its limitations. ${ }^{93}$

Detroit is not just one story. Rather, it is a collection of many overlapping and contradictory stories.

${ }^{93}$ Edward W. Said \& Jean Mohr, After the Last Sky: Palestinian Lives (New York: Pantheon Books, 1986), 38. 
Nevertheless, Moore, unlike most photographers in Detroit, deserves praise for actually including people in many of his shots, and he documents kids walking to school or hanging out on the corner. These give a sense of the banal and everyday that is often missing in images made of the city, and gesture at the "inarticulate rich thereness of place," that Said has referred to. ${ }^{94}$ In general, people are a notable absence in Detroit images. The photo sets by Hemmerle and Witold Rybczynski are completely devoid of human figures and in Marlowe's fifty two photographs the most direct evidence that the city still has residents is found in one image that features bullet holes in the wall of a building. ${ }^{95}$ And if artists do happen to catch human life in the frame, it is often blocked out by weighty words about decay, collapse, and failing empires. For example, in the work by Marchand and Meffre, the editors of the series juxtapose an image with the following quote:

Ruins are the visible symbols and landmarks of our societies and their changes...the volatile result of the change of eras and the fall of empires. This fragility leads us to watch them one very last time: to be dismayed, or to admire, it makes us wonder about the permanence of things. ${ }^{96}$

But there is plenty of life in this image, and the photograph appears to be of a footrace or political demonstration. Other evidence of people can be less direct. In many Detroit ruin images there are traces of people making use of these spaces in the form of graffiti and informal living quarters for the homeless or even, admittedly, Marlowe's bullet holes. Life

\footnotetext{
${ }^{94}$ Said and Mohr, After the Last Sky, 28

95 Witold Rybczynski, “Exploring Detroit's Beautiful Ruins," Slate.com, May 18, 2009 (accessed October 10, 2009).

96 "Detroit's Horrible, Beautiful Decline: Two French photographers immortalize the remains of the motor city on film," Time.com, http://www.time.com/time/photogallery/0,29307,1882089,00.html (accessed April 15, 2009).
} 
even continues in the ruins in the form of entertainment: sites like the train station and the Packard Plant have long been locations for late night dance parties and the emergence of Detroit Techno, a fact periodically pointed out by journalists. ${ }^{97}$ But actual residents—and not just their dystopian traces—are all missing from the city's representations. Even Time, in their somewhat optimistic piece on the city's future, uses a cover by Marchand and Meffre that features two people walking down an alley in the Packard Plant. Not only is the image deceptive due to the fact that it substitutes an alley inside an abandoned building for what appears to be a street, the cover also draws from what has become the standard color palette of Detroit images - muted grey - to convey the typically morose image of the city. And finally, and most disconcerting, are the human figures, dwarfed by the surrounding ruin and rendered into almost ghostly presences rather than actual people. ${ }^{98}$

It should be noted that this is not to suggest that there is some sort of photographic truth to be found in Detroit. These photos are as representative of the city as any other. As Herron argues:

The city is neither one thing nor the other, neither the empty dark places nor the shiny restored ones; it is both at once, back and forth: a kind of monumental gestalt puzzle. ${ }^{99}$

But what is unsettling about these images is their stylistic and thematic uniformity, alongside their tendency to cover the same ground. Imaginative Geographies are referential; they enable particular experiences of particular places. And in Detroit's case, these images

\footnotetext{
${ }^{97}$ For more on "Life in the Ruins," see historian and reporter Bill McGraw, "Historians in the Streets: Life in the Ruins of Detroit," History Workshop Journal 63 (2007), 289-302.

${ }^{98}$ Time, October 5, 2009.

${ }^{99}$ Herron, AfterCulture, 27.
} 
become increasingly limited. Recent dystopian tour guides made of the city follow similar routes as these photographs, and guides suggest ways to find the most prairie-like and the most devastated neighborhoods in the city. Whatever the aesthetic appeal, there is something disconcerting about touring a city's poverty in search of picturesque vistas. ${ }^{100}$

And images are not just aesthetic so much as they are power-laden, as Rose makes clear. Finding aesthetic appreciation in Detroit's decay—despite the attempts to somehow differentiate from other ruin documenters — is a kind of voyeurism that, regardless of intent, functions as mockery. Rather than creating and distributing images that gesture at the complications inherent in Detroit's poverty, or the entanglements between policy, history and race that continue to create Detroit's present, or the vibrant middle class neighborhoods in the city, Detroit's documenters take the easy way out, substituting aesthetic wonderment for political engagement. There is no doubt that Detroit is a city of ruins, or at least a city with quite a few vacant buildings, but it is also a work-in-progress, a city decidedly in the present. As Herron suggests, it is all these things.

But how the city is represented is an important part of the city's political present. In the new entrepreneurial city, where urban competitiveness and neoliberal ideology dominate the discourse, cities are left with few options. Faced to compete with cities throughout the globe and eviscerated by capital mobility, large cities like Detroit are left to fight for limited tourist dollars amidst crisis. The result, seen across the globe in ailing rust belt cities, is an

\footnotetext{
${ }^{100}$ An August 2010 editorial in the New York Times makes a similar argument. See Kennedy Odede, "Slumdog Tourism," The New York Times, August 10, 2010.
} 
increase in street cleanups, promotional images and the creation of tourist bubbles. ${ }^{101}$ In this context, conflicts over imagination and representation become increasingly important, and image sets of the city often play a role in political decision-making. Additionally, sites like the heavily photographed Michigan Central Station and Tyree Guyton's Heidelberg Project, which highlight decay and open up Detroit's failings for public viewing, are quickly embroiled in the conflicts over vision that characterize many of Detroit's redevelopment attempts. The ways in which city politicians have dealt with both the train station and Heidelberg demonstrate the ways in which Detroit images circulate back into the city and lead to changes in the city's actual morphology.

\section{The Michigan Central Station}

The Michigan Central Station is undeniably the most evocative and consistently publicized ruin in Detroit. Built in 1913 by architects Warren \& Whetmore and Reed \& Stern, the building functioned as a train station until 1988, and has stood empty since. Owned by Manual "Matty" Maroon and the Detroit International Bridge Company, many renewal plans have been put forth but none have come to fruition. Instead, the structure has played hosts to raves, art installations, urban tourism and exploration, and has been the site of many recent films, including big budget Hollywood productions like Michael Bay’s Transformers and The Island as well as John Singleton's Detroit western Four Brothers. Through these representations, the station has come to function as a kind of dystopian entryway into the city.

101 Judd, "Constructing the Tourist Bubble." 
Camilo José Vergara, who I will discuss in more detail in the next chapter, gave voice to the station's capacity to evoke emotional responses when he noted in 1999:

I have photographed the former Michigan Central Railroad Station at least twice a year for eight years, but I refrained from going inside until 1995. The station, a huge, austere neo-classical building... is now derelict, isolated: a menacing presence. 102

In another book, Vergara notes that "More than any other derelict space I've seen, this fine neoclassical structure says, "we were once a great city.",103 Vergara is but one example of someone who has found the station to serve a muse-like quality and he has photographed it for almost two decades. Despite its private ownership, the station has come to function as the premiere icon of Detroit's decay, and has served as a source of inspiration for photographers and journalists interested in the city.

Yet as I have argued previously, images do not exist in a void, and the consequences of their production are often unintended. Through their construction of particular imaginative geographies catalogers of Detroit's urban decay help to construct set pathways and experiences in the city. But like all imaginative geographies, these representations are not just citational and self-referential but also deeply material. Images made of the city circulate and influence decisions made about urban development. By constructing images of Detroit's ruins, photographers and journalists are not just naturalizing decay in the abstract; they actually contribute to it. As one Detroit city employee noted on the condition of anonymity,

Does the city feel political pressure when that stuff is out on the internet? Absolutely. We lost a building to that that was structurally sound. It looked

\footnotetext{
${ }^{102}$ Vergara, “Michigan Central Railroad Station, Detroit," Michigan Quarterly Review, 38, no. 3, 1999.

${ }^{103}$ Vergara, American Ruins, 214.
} 
terrible on the video clip that was sent out onto the internet. We had the money to do it, it could have been completely restored and yeah, that one went down. And to me, that was really sad. We had money earmarked for it; the money was there. ${ }^{104}$

The employee was referring to the William Livingstone Mansion, commonly referred to by Detroit ruin tourists as "Slumpy." The site was demolished in 2007, presumably as a response to the house's online popularity. A similar story can be told about the Michigan Central Station. In March 2009, Detroit's city council voted to demolish it, a decision that provoked outcry from preservationists and interested outsiders. The station has not yet been demolished - and seemingly will not be any time soon-but the call to tear it down says quite a bit about the intersections between representation and place. The attempt to tear down the structure was made due to the station's prominence in representations made of the city. It is the station's status as an icon of decay that compels its demolition.

In an NPR piece, Celeste Headlee makes reference to the station's iconic popularity. Simply entitled An Abandoned Symbol of Detroit's Better Days, Headlee quotes University of Michigan professor Reynolds Farley. He speaks to the station's status as icon when he notes, "You can't spend time in Detroit without seeing this building... When I've given tours to people who've never been to Detroit before, one of the first things they ask is, 'What is that building over there?",105 Even the spokesman for the current owner of the station admits that the building is probably being torn down because it's a "visual icon to the decay of

\footnotetext{
${ }^{104}$ Anonymous, interview by author.

${ }^{105}$ Celeste Headlee, "An abandoned symbol of Detroit's better days," NPR, June 2, 2009, http://www.npr.org/templates/story/story.php?storyld=104873009.
} 
Detroit,"106 a point made totally absurd considering the fact that Maroun is the owner of the building and has helped facilitate its fall into dereliction. Another NPR piece, from June 2009, asks if the building is an eyesore or a landmark, and a local news source argues that "Michigan Central Depot has been the epitome of urban blight for two decades. The mammoth structure sits abandoned, a constant reminder of Detroit's tough times." ${ }^{107}$ An editorial in the Detroit Free Press argues that,

In its highly visible decay, the station has become more than an eyesore: Featured in Camilo José Vergara's "American Ruins," the depot has morphed into an iconic, international symbol of Detroit's decline. Think about it: If you come into Detroit from the south, along I-75, or across the Ambassador Bridge from Canada, the depot is one of the first structures you see along the skyline. It's a shabby welcome mat for the city, and a ghastly front door to the southwest Detroit neighborhoods that surround it. ${ }^{108}$

The author of the article continues by noting, "If the structure cannot contribute to Detroit's rebirth, it should no longer define its decline" and refers to the station as "the ghost of southwest Detroit,"109 with a "gap-toothed, airy façade," “a spooky symbol of the city’s decay." The article concludes: "The ghost of Southwest Detroit shouldn't be allowed to haunt its neighbors, or this city's image, for another year." ${ }^{\prime 10}$ A series of articles in Detroit echo these points. David Josar of the Detroit News refers to the building as "the haunting symbol of Detroit's storied past and recent failures." $" 111$ An earlier editorial argues "the 18-

\footnotetext{
${ }^{106}$ Corey Williams, "Detroit wants blighted old train depot demolished," USA Today, April 7, 2009.

107 "Still No Decision on Old Depot's Future" My Fox Detroit, May 18, 2009, http://www.myfoxdetroit.com/dpp/news/local/090518_train_depot.

${ }^{108}$ Free Press Editorial, “One last chance for ghost depot,” Detroit Free Press, April 26, 2009.

109 Ibid.

110 Ibid.

111 David Josar, “Detroit council: Demolish train depot on Moroun's dime,” Detroit News, April 8, 2009.
} 
story, 500,000-square-foot behemoth literally haunts the southwest Detroit neighborhood where it stands". ${ }^{12}$ The "eerie hulk [on] Detroit's horizon" is a symbol of "how awfully government and private owners work together to be sure that one building doesn't decimate an entire neighborhood." abandoned building," 114 while another refers to it as "what many call Detroit's biggest eyesore." 115

Preservationists, on the other hand, offer solutions to the station that reflect the site's beauty, and when the demolition order was first expressed, many wondered why the Detroit city government was choosing to demolish the train station rather than any the countless abandoned buildings in the city. John Mohyi, head of the Michigan Central Station Preservation Society, made this point directly in an interview, noting:

...you don't want to lose your history and I think that Detroit is a little too quick to demolish buildings these days and I mean, there's over something like 10,000 buildings that are abandoned. Why don't we start with those? And the one next door to the Michigan Central Station, that needs to be torn down. That's a complete eyesore. But it's amazing how they, you know, decide to start with the good buildings first. ${ }^{116}$

Mohyi is not interested in preserving the site as a ruin, but instead in redeveloping it.

In a March 2009 article in the New York Times, he acknowledged this by noting, "It's the quintessential example of urban decay in Detroit. To see redevelopment of that station would

\footnotetext{
${ }^{112}$ Free Press Editorial, "Get the message, Moroun and city: do something about train depot," Detroit Free Press, April 9, 2009.

${ }^{113}$ Free Press Editorial, "Get the message, Moroun and city: do something about train depot," Detroit Free Press, April 9, 2009.

${ }^{114}$ Bill McGraw, "Web site captures decline of Detroit's iconic train depot," Detroit Free Press, April 9, 2009.

${ }^{115}$ Bill Shea, "Detroit city council wants Michigan central depot torn down," Crain's Detroit Business, April 7, 2009.

${ }^{116}$ John Mohyi, interview by author, August 4, 2009, Detroit, MI.
} 
have a major impact on morale."117 But Mohyi, a lifelong resident of the Detroit metro area, had never seen the station before the decision to tear it down was made, a fact that demonstrates his somewhat limited engagement with the city. ${ }^{118}$ Additionally, his insistence on the beauty of the site also gestures at the ways in which the beauties of dereliction often relate to one's position in relation to those spaces. For those living next to dangerous and problematic vacant buildings, romanticist wonder is subsumed under the realities of crime, poverty, and limited resources. For many in Detroit, sites like the station are embarrassments as well as dangerous spaces, prone to fire and criminality. Efforts to demolish the station reflect this tension well.

And furthermore, by juxtaposing Detroit's former grandeur with its current ruin in a dramatic way, the station compels Detroiters to really engage with the politics of urban image-making as they relate to the city of Detroit. The result is that the decision to demolish the station promoted city-wide conversations that asked questions about the intersections between representation and power in a direct way. Detroiters are not blind to the national attention that sites like the train station receive, and decisions to tear down iconic sites have much to do with the popularity these sites receive online and in-print. But the decision to tear down the station demonstrated the ways in which demolition is a means of asserting a vision of the city that stands in opposition to the image of Detroit as a ruin. It is inarticulate but effective.

\footnotetext{
${ }^{117}$ Susan Saulny, "Seeking a Future for a Symbol of a Grander Past," The New York Times, March 5, 2010.

118 John Mohyi, interview by author, August 4, 2009, Detroit, MI.
} 
Councilwoman Barbara-Rose Collins, who authored the resolution to charge owner Maroun for the demolition, makes this point directly: "we can't wait any longer...It's been an eyesore for too long." 119 Mayoral spokesperson Daniel Cherrin echoes this in remarkably similar language when he notes, "Its an eyesore. What once stood as the city's architectural treasure, now sits as a symbol of blight in the city." ${ }^{, 20}$ Jeff Gerritt of the Detroit Free Press agrees in a November 2009 editorial:

For symbolic reasons alone, the city must rehabilitate or raze the Packard Plant and the Michigan Central Station. They're not nearly as corrosive as the 78,000 vacant buildings that blight Detroit's neighborhoods, but they have come to represent and define our city. They're the first stop for out-of-town journalists trying to get a whiff of Motown's rusted gears, and poster shots for documentaries such as History Channel's 'Life After People.' Detroit's inability to redevelop these two imposing sites reflects its inability to control its image and destiny. ${ }^{121}$

In these framings, the decision by Detroit's city Council to tear down the building makes some sense, and part of me is content to watch the structure come down. The violence inherent in rendering a city's poverty into romanticized representations makes sites like the train station feel compromised and ugly. Given the racial dynamic inherent to anything involving Detroit, it is easy to understand and sympathize with Detroiters who are unwilling to preserve sites that reflect white tourists' engagement with the city, especially when they are sites that gesture towards the history of a city that long marginalized African-Americans. Sites like the Depot are implicated in this racial dynamic, although it is really places like the

119 David Josar, “Detroit council votes to demolish Michigan Central Depot, charge owner," Detroit News, April 8, 2009.

120 Williams, "Detroit wants blighted old train depot demolished."

121 Jeff Gerritt, “...And Ridding the City of its Major Symbols of Decay,” Detroit Free Press, November 1, 2009. 
recently demolished Tiger Stadium that articulate the complicated and racialized politics of nostalgia, preservation and representation in Detroit. Sites like the train station are nevertheless deeply embedded in the power dynamics of image-making, and efforts to demolish iconic sites can be seen as a kind of counter-mapping against popular imaginaries of the city that stress emptiness and ruin. In this way, by demolishing iconic sites, Detroiters are arguably asserting their presence in the city in a real way.

In Herron's 1993 book, AfterCulture: Detroit and the Humiliation of History, he gives voice to the violence of representation by detailing a story of being nearly assaulted on a city bus by a man suffering from mental illness. Herron concludes the book with this quote:

The man had a right to defend himself, for fear of how he might be used. But life had deprived him of the resources that a real defense would require. History has been only slightly more generous to Detroit. Which is to say, it's easy to make a 'madman' of the sad, humiliated life, just as it's easy to find 'true tales' to tell about the city. And it's understandable that people would want to do so: to keep their guilts and fears and anxieties at bay. I think about the madman, then, and I know he wasn't shouting at no one. He was talking to me. $^{122}$

Herron here is talking about the inherent violence of representation, and the right of the city to assert its present, no matter how incoherent or muddled. In this way, demolition can function as a kind of language in the symbolic vocabulary of the city.

Yet it is still symbolic rather than substantive. Too often, for cities mired in what Harvey has called the entrepreneurial era of urban governance, the politics of symbolism are used as stand-ins for the real tasks of providing jobs and ridding cities of corruption. Both preservationists and supporters of demolition privilege iconic sites over the more mundane

122 Herron AfterCulture, 209. 
realities that define most Detroiters' lives. It is not in sites like the train station where lives are organized and lived, but instead it is in the vernacular landscape, the neighborhoods that are often ignored by Detroit's ruin documenters, as well as the city government itself. Jeff Gerritt's pleas to demolish the structure as a demonstration of the city's agency—as well as his earlier plan to keep the structure as a symbol of "how far we have fallen, and how far we must travel together-are policies that function in the realm of symbolism rather than substance." ${ }^{123}$ It is easy to be reminded of sports commentators' constant mention of the city's poverty when discussing its sports teams, as though a victory by the Detroit Lions makes up for a unemployment rate that is close to fifty percent in parts of the city.

In their only article on the train station, Detroit's African-American

newspaper The Michigan Citizen, asks "Is there anyone else that sees what a waste of money it is to destroy these buildings?" The author continues:

People in government have to stop looking behind and just thinking tear it down. They must look ahead and ask, how will this help grow Detroit? Putting dollars in as many local pockets as possible. Provide accessible, affordable and commercial retail spaces downtown and in the neighborhoods. ${ }^{124}$

There is no mention of embarrassing eyesores, symbolic affronts, or suburban interlopers. Instead, the authors seem to both call out the corrupt and inefficient city council and the hostile suburbs. They articulate a middle ground, a position that admits the economic importance of historic buildings without drowning in weighty rhetoric about history and architecture in a city that has heard too much of that. A similar challenge has been made by

\footnotetext{
${ }^{123}$ Jeff Gerritt, "Detroit's 'Ellis Island' still impresses," Detroit Free Press, April 26, 2009.

124 "Tearing down will not stimulate," The Michigan Citizen, April 12, 2009.
} 
Tyree Guyton's Heidelberg Project, a multi-block art installation on Detroit's East Side.

Guyton's project offers a way of thinking about the challenging and positive work that art and image can do in a city like Detroit.

\section{The Heidelberg Project}

"You'll think I'm crazy," Tyree Guyton has said, "but the houses began speaking to me....Things were going down. You know, we're taught in school to look at problems and think of solutions. This was my solution." ${ }^{, 25}$ Guyton's solution was remarkably unorthodox. He chose to paint massive polka dots all over abandoned houses, cover trees in tricycles, assemble collections of discarded shoes and vacuums, and cover abandoned houses in pennies. Him and his late grandfather Sam Mackey, in the words of Detroit poet John Sinclair, "turn[ed] their neighborhood inside out." ${ }^{126}$ In a city where the memories of the 1967 riots still haunt political discourse, racial conflict characterizes much of the political and economic situation, and tourists document the city's blight for aesthetic consumption, Guyton's work was not neutral. Instead, it was explicitly political. In his own words:

In 1964, when I was nine, my Grandpa Mackey gave me a paintbrush and told me to paint the world. Grandpa Mackey was my mentor and my best friend. He also told me that he could see the wind blow, which I could come to understand much later in my life. There was a time, growing up in the $60 \mathrm{~s}$, when it felt like hell - a time of total chaos between blacks and

\footnotetext{
125 John Beardsley, "Art or Eyesore?" in Connecting the Dots: Tyree Guyton's Heidelberg Project, ed. The Heidelberg Project (Detroit: Wayne State University Press, 2007), 40.

${ }^{126}$ Wendy S. Walters, "Turning the Neighborhood Inside Out: Imagining a New Detroit in Tyree Guyton's Heidelberg Project," The Drama Review 45, no. 4 (Winter 2001), 64.
} 
whites, the murders of those fighting for equal rights, the black power movement, the Vietnam war, and the riots of 1967 in Detroit and elsewhere. Detroit, our great city, has been burning ever since, and so have the people....In 1986 I took my art to the streets of Detroit. The community where I grew up had become characterized by drugs, crime, prostitution, and gangs. I watched, in horror, the deterioration of my neighborhood....I set out on a mission to change my environment. I used what was available, and so it was from the debris of the neighborhood that I created the Heidelberg Project landscape. There was no plan and no blueprint, just the will and determination to see beauty in the refuse. My work became controversial, but it was also a medicine for the people."127

Over the last 22 years, Guyton has continued to create, establishing a multi-block open-air art installation that is visited by thousands of tourists every year. Countless visitors come to see the strange disfigured and almost cartoonish explosion of color and energy that characterize the project. Additionally, Guyton has won the Spirit of Detroit award as well as the Michigan Artist of the Year Award, and is currently in the process of building the "House That Makes Sense," a house entirely covered in pennies that will serve as a center for youth art programs. In recent years, Heidelberg has expanded into community development, including the Youth of Heidelberg Program, Art In Da Hood, and a collaborative project with Bunche Elementary School to teach art education. Heidelberg is a dramatic success in many ways, and an inspiration in many others. It has, however, not been without its detractors and controversy. Responding to complaints from neighbors, the Detroit city government partially

\footnotetext{
${ }^{127}$ Tyree Guyton, "From the Artist" in Connecting the Dots: Tyree Guyton's Heidelberg Project (Detroit: Wayne State University Press, 2007), vi-viii.
} 
tore the project down twice, once in 1991 at the behest of Coleman Young and once more in 1999 under the leadership of then mayor Dennis Archer. Like the Michigan Central Station, the decisions to tear down Heidelberg were primarily a product of the complicated politics of representation found in the city.

It is hard to generalize about the reasons for demolition, especially given the immense differences in the leadership of Mayors Young and Archer, but the two efforts speak to the heightening of a particular kind of visibility brought forth by Guyton, one that opens up Detroit's dereliction to be viewed. While largely responding to citizen and neighbor complaints, of which there have been many, the decision to demolish Heidelberg twice in a city with thousands of abandoned properties has to be seen in primarily symbolic terms. For a city long maligned by the rest of the country with a long history of failed urban renewal, Heidelberg is a dramatic affront to the city. Instead of downplaying decline and decay in favor of neutral images of a middle class Detroit, Guyton calls attention to the city's faults, making clear who is in need in the city. But this is not an image that privileges aestheticized and depopulated images of the city; instead, Guyton is asserting that there is still life within the rubble. And this is precisely the problem: Guyton is making explicit the fact that in many ways, Detroit politicians have failed their citizens. In a city that is still reeling from the racial problems of the sixties and the associated tensions and conflicts, Guyton, in the eyes of Detroit's politicians, is opening up the city's embarrassing secrets for all to see. This complicates an easy racial binary, as Guyton, an African-American artist, is both attacking the city government as well as those who would ignore Detroit and its residents. 
Heidelberg articulates the kinds of fractured narratives I wished for in discussing Edward Said. There is no closure or fixity in his work. Instead, Guyton calls attentions to the margins of the cities - the neighborhoods and those left behind by redevelopment plans_-but his vision is neither entirely comforting not entirely disturbing. It disorders the city, and places objects in new relationships and configurations. And instead of ignoring the residents of Detroit in favor of aestheticized images of renewal or decline, Guyton instead uses the detritus of decline to envision a possible future. He is not ignoring the dramatic problems that are facing Detroit; instead, he is calling attention to them in a way that humanizes and dignifies the residents of Heidelberg Street. As David Sheridan argues:

Like many cities, Detroit is 'centered' in the sense that there is a geographic, symbolic, and economic focus on 'downtown.' Efforts at renewal (eg. the RenCen, two new stadiums, casinos, and the restoration of old theaters) are aimed at the downtown area, ostensibly on the 'trickle out' theory...but this strategy is only partially successful at best, and one repeatedly hears the criticism leveled at city planners: don't forsake the neighborhoods. Heidelberg, as something organic to the neighborhoods, a project literally intermingled with people's houses and homes, is a form of this criticism: it is a way of decentering the city, a way of saying, we are here, on the margins--don't forget us."128

In opposition to the neoliberal rhetoric of entrepreneurial cities, Guyton is envisioning an alternative that stems from the real spaces of the city, from the creative potential of its residents, and from the kind of cross-cultural connections bred by art and creativity. And he

${ }^{128}$ David Sheridan, “Making Sense of Detroit,” Michigan Quarterly Review 38, no.3 (1999): 346. 
is demanding that policymakers, both local and national, realize what is happening behind the glitzy images of renewal. In the lengthy but necessary words of Herron:

[Guyton's] houses literally vomit forth the physical elements of domestic history...The magma of discarded lives; these visible tokens of a humiliated history. In that sense, Guyton has constructed a shrewd parody of the inside/out logic of renewal. He has done for the poor what conversion does for the middle class. Like the little boutiques and restaurants that occupy the formerly domestic areas of historic interiors, Guyton's 'project' similarly converts private space to public spectacle. But the results in his case are not so much reassuring as they are disturbing. It is impossible to look at the Heidelberg Project and not imagine that something terrible has happened to cause this explosion of physical deformity. ${ }^{129}$

In the context of dramatic high profile redevelopment, including the 1977 construction of the Renaissance Center as well as recent efforts to develop the downtown riverfront, there is a profound danger of losing sight of streets like Heidelberg. Guyton is calling our attention to them, by playing with visibility and daring visitors to imagine a city both horrific and hopeful. By articulating a vision of the city that both dramatizes its decline while highlighting its humanity, Guyton and Heidelberg reverse the vision so often conferred on Detroit. Heidelberg is both dystopian and utopian, which complicates the binary that Sheridan argues is foundational to most representations of the city. ${ }^{130}$ And Guyton's reversal of the tourist bubble — which actually forces tourists into the city itself-has the possibility of being profoundly destabilizing in a city rife with racial and territorial binaries and conflicts. 
The result, unsurprisingly, is conflict. The responses to the increase of tourism by critics demonstrate that visibility is not just related to what is being made visible; it is also connected to who is subsequently able to see.

This is an important distinction. To many Detroiters, Heidelberg is threatening because it opens up hidden neighborhoods to public scrutiny once again. In the complex and divisive realities of race and uneven development in Detroit, Guyton is willfully drawing suburban outsiders into the heart of the city, the same people who document Detroit's ruins. Critics argue that white tourists construct an exoticized other, braving the ghetto as though it were a foreign country and reinforcing stereotypes of the city. Heidelberg Street resident and project critic B.B. Odums makes it clear why this is so problematic, by arguing:

If we rode up and down the streets in the suburbs we'd get picked up because we're black. Every summer night we've got people riding up and down and looking at what we're doing. It's an invasion of privacy. They look at us like we're animals on display. I got so angry last summer that I said, 'What in the hell are you looking at? ${ }^{131}$

Odums picks up on one of the many conflicts that characterize Heidelberg, calling into question just who Guyton has the authority to speak for and who is the intended audience. In this way, she articulates the ways in which Heidelberg — and its associated conflicts - are a clear demonstration of the difficulties inherent in trying to represent the fractured geographies of Detroit. Supporters argue that Heidelberg is a remarkable way of opening up views and connecting people across racial and class lines, and in recent years, this perspective seems to have taken hold. Heidelberg has remained largely untouched since

\footnotetext{
${ }^{131}$ Michael Hodges, "Heidelberg and the Community," in Connecting the Dots: Tyree Guyton's Heidelberg Project (Detroit: Wayne State University Press, 2007), 56-57.
} 
1999, and the city seems to have ceased their opposition to the project. Guyton has slowly increased the community development components of the project and continues to focus on establishing art programs in local schools and working with kids on art projects and job skills training. Additionally, Guyton has become increasingly prominent in art circles, with Heidelberg pieces being show at museums in Europe, Latin America, and the U.S. The Heidelberg Project still stands, and in the 22 years since its creation it seems to no longer raise the kind of controversy it once did.

\section{Conclusion}

In much of the city, however, the battles still go on, and while Heidelberg has been given a reprieve, one can see the politics of representation in the current efforts to demolish the Michigan Central Station. These conflicts demonstrate the work that images can do. In Detroit's case, images made of the city not only depopulate the city aesthetically, but they also contribute to policies that ultimately lead to further demolitions. Photographers who construct limited and romanticized visions of Detroit's decline are working to depopulate the city and arguably pave the way for the city's present state to be seen as natural or inevitable. In doing this, they are part of the process by which landscape becomes unreadable.

But spaces like Heidelberg — or other examples of local artists who play around with the overwrought language of ruins and myth — demonstrate how open many of these images can be. There is a voyeurism to ruin imagery that is problematic, but the violence inherent in Detroit's decline also suggests an engagement with the city that is emerging. Many who celebrate Detroit's decline also highlight its charms, and these are often parts of the same 
project. As I will argue further in the next chapter, images made of Detroit suggest ambivalence, as both artists and consumers seem unsure of what to make of a city so racked by economic collapse. Finding a way to imagine and represent Detroit without celebrating its poverty or hiding it is the start of an attempt to understand the city as more than just the paramount example of deindustrialization. An engagement with Detroit's varied and uneven cityscape — and its connections to broader culture and national identity, rather than just its distance - is suggested by projects like Heidelberg and needs to be celebrated if Detroit is going to continue to receive the attention it presently does. 


\section{Chapter 4: "Wild Wild Midwest": Landscape and Nature in Detroit}

In a 1993 article, David Harvey notes, "there is in the final analysis nothing unnatural about New York City." He continues, "human activity cannot be viewed as external to ecosystemic projects. To view it so makes no more sense than trying to study pollination

without bees or the pre-colonial ecosystem of the northeastern USA without the beaver."132 Harvey's dictum is somewhat self-evident, at least to geographers, but still presents a challenge. Over the past three decades, Environmental Historians, Geographers and Ecologists have sought to problematize the idea of static ecosystems that exist outside of human history. In urban contexts, scholars have conceived of hybrid urban ecologies as a way of tangling the human and nonhuman as well as the city and the country more broadly. Similarly, urban planners and developers have found ways of bringing nature back into the city as part of a more practical engagement with urban ecosystems. For these scholars, activists and planners, finding nature in the city — in one version or another of urban ecology — has become a way to blur divisions between the natural and the artificial in favor of hybrid urban spaces and imaginaries. Yet there are lingering questions about how well these new ecological formulations are taken up in more vernacular contexts. As Raymond

132 David Harvey, "The Nature of Environment: Dialectics of Social and Environmental Change" in Real Problems, False Solutions (London: The Merlin Press, 1993). Cited in Nik Heynen, Maria Kaika, and Erik Swyngedouw, "Urban Political Ecology: Politicizing the Production of Urban Natures," in In the Nature of Cities: Urban Political Ecology and the Politics of Urban Metabolism, ed. Nik Heynen, Maria Kaika, and Erik Swyngedouw (London: Routledge, 2006). 
Williams argued in his essay, Ideas of Nature, the enlightenment division between people and the wild is a foundational part of post-enlightenment western ways of thinking. ${ }^{133}$

Dating back at least to the mid-1980s, catalogers of Detroit's decay have used natural imagery and metaphors to heighten the effect of representations made of the city. For many, Detroit seems to have gotten so bad that it is being reclaimed by a kind of redemptive nature. In this chapter, I focus on the ecological imaginaries that are present in these representations made of Detroit. I use these images in order to ask questions about the ways in which urban nature is being conceptualized and the ways in which understandings of nature are made to work politically. I argue that representations made of Detroit actually use broad cultural understandings of nature — what Bill Cronon has called the "wilderness ethic" — to further obscure and naturalize the processes that have constructed the city's urban landscape. ${ }^{134}$ Furthermore, rather than help to construct an urban ecological imaginary that understands cities as diverse assemblages of human and nonhuman matter, images made of urban ecology in Detroit actually use nature-society binaries as a way of furthering a conceptual displacement of nature from the city.

After two subsections in which I detail different approaches to urban nature found in Detroit, I conclude by returning to the fundamental ambivalence of these images. Despite their problematic political work, I argue that these images are documents of ambiguity, and gesture at some of the newly emerging ecologies found in post-industrial cities more broadly. Finding nature in the city—and understanding the presence of nature as an effect of

\footnotetext{
${ }^{133}$ Williams, "Ideas of Nature."

${ }^{134}$ Cronon, "The Trouble with Wilderness."
} 
urbanization itself and not just a counter — is a difficult undertaking. These images and the responses to them make it clear that understandings of hybridity are both challenging but also being worked through by popular audiences.

\section{Pheasants}

Photographer and sociologist Camilo José Vergara is arguably the scholarly forebear to Detroit's ruin tour industry. Vergara has engaged in a decades-long investigation into America's declining inner cities that has yielded a series of books and articles that function as a way for Vergara to explore the "soul" of neighborhoods amidst "dereliction and destruction." 135 In a way, his is the official voice that sits behind the literature dealt with in the previous chapter, but his project suggests a rather different tone. Instead of effacing the human presence from Detroit, as most catalogers of the city do, Vergara actually insists on including people in the frames. In his 1999 book, American Ruins, he notes, "When taking a photograph I often wait for humans or animals to pass, giving a sense of scale and showing how they interact with the environment."136 Vergara himself defines his project as about social justice but also much more:

Social justice, however, is not my only concern. I also study the emergence of new styles; discuss the ways in which ghettos contribute to our national identity; urge the development of policies regarding the clearing, preservation, restoration, and stabilization of ruins; and try to foster awareness of the loss of so much first-rate architecture. To document what is physically happening to

\footnotetext{
${ }^{135}$ Vergara, American Ruins, 16.

${ }^{136}$ Ibid.
} 
American cities and explore the consequences, then, constitutes a realm of its own, one deserving much greater attention than it has so far achieved. ${ }^{137}$

Towards these ends, Vergara attempts to construct a typology of American inner cities in which he does not demean residents' aspirations yet does critique their surroundings as examples of "the exclusion of so many poor, minority people from mainstream society."138 Some of his more striking photographs are products of his lengthy engagements with places like Detroit, in which he photographs one site over the course of years or even decades. His photographs of individual doors over time are particularly evocative and gesture at the pacing and extent of urban decline.

Yet there is a lurking romanticism in Vergara that is troubling. Despite his concerns for social justice and his desire to humanize American ghettos with the voices of residents, Vergara is also drawn to the aesthetics of decay, and seems unable to escape his own fascination with declining cities. Vergara describes his initial forays into American cities as a product of wanting to engage with the realities of working-class urbanism in Gary, Indiana: "With my eyes smarting from the smoke of the steel plants, I saw people gambling and drinking. I wanted to join them, but I felt alien and had little money; I could only look."139 In sites like Gary, Vergara found "the challenge of [his] life," places where "[he] became so attached to derelict buildings that sadness came not from seeing them overgrown and

\footnotetext{
${ }^{137}$ Ibid., 3.

${ }^{138}$ Ibid., 9.
}

${ }^{139}$ Ibid., 23. 
deteriorating — this often rendered them more picturesque — but from their sudden and violent destruction.",140

This tension in Vergara's work - between aestheticization and an active engagement with poverty and social justice — is one of the central ambivalences in Detroit imaginaries. But what is especially irksome about Vergara's project, and seemingly at odds with his own engagement with questions of justice, are the ultimate suggestions that Vergara makes about what to do for the city. In one example, Vergara suggests turning Detroit's icon of decay, the Michigan Central Station, into an abbey or monastery, in order to dub Detroit the "city where the Middle Ages work."141 In another famous plan, Vergara argued that Detroit's predepression skyscraper core should be preserved as an "urban monument valley," an American Acropolis where tourists gaze at the skyscrapers as they crumble.

Vergara's plan assumes a kind of urban ecology as a central component, an idea that immediately brings to mind Georg Simmel's idea of "the ruin." Vergara insists that for the American Acropolis plan to be successful:

Midwestern prairie should be allowed to invade from the north. Trees, vines, and wildflowers would grow on roofs and out of windows; wild animals, goats, squirrels, possums, bats, owls, ravens, snakes, insects, and perhaps even an occasional bear would live in the empty behemoths, adding their calls, hoots, and screeches to the smell of rotten leaves and animal droppings." 142

\footnotetext{
${ }^{140}$ Ibid., 23.

${ }^{141}$ Ibid., 58.

${ }^{142}$ Vergara, The New American Ghetto, 220.
} 
This plan was unsurprisingly not well-received. As one Detroit City employee pointedly asked me when discussing this plan, "Who are we? The animals in the park?"143 And yet Vergara was shocked. And so:

We may never see the buildings losing their stigma under the cover of nature: structures part man-made, part natural, their supporting frames exposed, their sides buckling, squirrels climbing up the vines. All I can do is to record the fading splendour of the buildings and the disjointed and anguished cries of those who try to make a home among them. Meanwhile, the wind moans through narrow canyons, and the near-empty People Mover creaks and curves along. There are stories of deer swimming from Belle Isle across the river to roam the empty streets among the skyscrapers. As officials plan to continue leveling, a space, able to restore our soul, waits to be discovered. ${ }^{144}$

As these quotes indicate, Vergara often uses natural metaphors and ecosystemic concepts to explain Detroit's ongoing decay. In this framing, nature in the city is a kind of co-constructer of urban decline. But Vergara's conception of nature in the city seems ambivalent — possibly a testament to the newness of the urban nature found in places like Detroit — and he often sees urban ecology as a vision of a utopian future as well as a dystopian present. Demonstrating this is the conclusion to his 1997 book, The New American

Ghetto, in which he notes:

Upon leaving Detroit, tired and bewildered, I saw a large male pheasant fly low in an arc over the freeway, landing on the grounds of a semi-abandoned housing project. The energetic clapping of its wings, the right browns of its plumage, its long tail passing so close to the dull cement of the highway - an unlikely phoenix. ${ }^{145}$

${ }^{143}$ Deborah Goldstein, interview by author, August 5, 2009, Detroit, MI.

144 Camilo José Vergara, “American Acropolis," New Statesmen \& Society 9, no. 385 (1996).

${ }^{145}$ Camilo José Vergara, The New American Ghetto (New Jersey: Rutgers University Press, 1997), 214. 
Vergara is not the first to notice pheasants in the city nor is he the last, and pheasants in the city are actually something of a recurring trope, dating at least back to the mid-1980s if not earlier. Yet Vergara gives Detroit's pheasants a peculiar metaphorical authority. They are not dystopian in this case but redemptive. In this way, nature's conceptual displacement from the city allows for readers to imagine a new future, one more metaphorical than substantive but nevertheless potent. Against the uninhabited "dull cement" of Detroit's decaying cityscape is a vision of nature as redeemer, an idea also articulated in many of Vergara's photographs. His photographs of seasonality in an abandoned building in Camden, NJ, for instance, provoke a similar emotional response.

In this tension between utopia and dystopia — what David Sheridan calls the central theme in representations of Detroit—Vergara gestures at the degree to which post-industrial urban nature is a presently in-between concept, one not yet adequately theorized. ${ }^{146}$ Whether the return of nature to the city presages a positive or negative future partially depends on how nature in the city comes to be understood and utilized. But however nature comes to be used, Vergara's image of urban ecology is one of displacement and a lack of belonging. For Vergara, the return of nature to the city is a violent process, as weeds and trees sprout from the roofs of buildings and cracks in the concrete. An online automobile magazine, Jalopnik, echoes this violence in an article titled The Feral Factories of Detroit. In it, the authors note:

...it's insidious, slow, unnoticed, but over time, the grasses grow tall, weeds fill in the cracks of once pristine and well-worn sidewalks, loading bays flood and become urban wetlands.... [Look at the images] to witness the

${ }^{146}$ Sheridan, "Making Sense of Detroit." 
astonishing power of nature to quickly return man-made structures to whence they came. ${ }^{147}$

Similarly, in an article on the now demolished Lafayette Building, which was famous for its trees sprouting from upper floors, Detroit-based journalist Charlie LeDuff quotes a laborer involved in the demolition. The man notes, "It's an epic battle trying to control nature and it looks like we lost....This tree. It's interesting, its beautiful, but the tree destroyed this building." ${ }^{148}$ A more scholarly account of this antagonism between nature and the city can be found in Andrew Moore's 2010 book of photographs entitled Detroit Disassembled, dealt with briefly in the first chapter. In it, Moore echoes the previous commentators and rejects Vergara's pheasants-as-phoenix idea. Instead, he argues:

Walking in Brush Park, a formerly grand nineteenth-century neighborhood, it's not uncommon to disturb a pair of pheasants who've been enjoying having the entire city block to themselves. As they fly off, just above the fields of grass, only a distant row of partially rehabilitated mansions gives a clue to the urban setting. These days it's not a phoenix arising from the ashes of Detroit, but two pheasants taking flight over weedy fields that mask piles of bricks and debris.

Although poor leadership on many levels has beset the city, the true engineer behind its disassembly is Janus-faced nature, which renews as it ravages this shadowed metropolis. An old factory floor's support might be weakened by a scrapper's blowtorch when he harvests a few choice I-beams, but its ice that brings the entire concrete floor crashing down. And it's the undisturbed vitality of nature that transforms a leftover soggy carpet into a lushly fluorescent bed of moss. ${ }^{149}$

Moore's argument is repeated by his publishers, who note that his is a project about "the human struggle to control nature by dominating the land. At the moment, nature seems

\footnotetext{
${ }^{147}$ Ben Wojdyla, "The Feral Factories of Detroit," Jalopnik.com, August 5, 2009.

${ }^{148}$ LeDuff, “Nature Takes Root as Detroit Landmark Rots," 2009.

${ }^{149}$ Moore, Detroit Disassembled, 119.
} 
to be winning in Detroit." ${ }^{, 150}$ Moore's photography at times suggests this opposition. In one of the concluding images in his book, entitled Yard, Car Wash Café, East Jefferson Avenue, Moore juxtaposes the residues of urbanity with what Simmel called the "downward-dragging, corroding, crumbling power of nature. ${ }^{, 151}$ In the image, two cars and an interstate sign lie next to a crumbling house, but the real star of the photograph is the ivy that covers everything. Underneath a grey and foreboding sky, the fall colors of the expansive ivy suggest that nature is in fact winning.

Other photographs convey different moods though, and suggest deeper connections between ecology and urbanism in the city. In one, Moore highlights a shelter built by a homeless person inside an abandoned factory. The shelter is composed of tarps, and the light shining through one of the tarps suggests a rather realistic waterfall. In another image, Moore photographs a carpet in an abandoned Ford plant. The image suggests that the floor is being slowly covered by moss, but it is increasingly difficult to see when the carpet ends and the moss begins. Through the doorway one can glimpse plant growth indoors. In both of these images, nature is integrated into these sites in a way that raises questions about interrelationships and entanglements. A plastic waterfall and a moss carpet are visions of hybridity, pulling in the viewer's perceptions and assumptions into the material spaces of the city. Moore forces the viewer to ask questions about what is natural and what is unnatural in these images.

\footnotetext{
150 In ibid., 123.

${ }^{151}$ Simmel, "The Ruin," 260.
} 
Other writers and photographers find ways of thinking about overlaps between natural and urban spaces in Detroit. Most prominent is the common idea of cities as organisms, an idea with a genealogy that is much too long for this paper. ${ }^{152}$ But journalist Kristin Palm gives voice to a kind of popularized urban organicism in a 2002 article for Metropolis. She notes, in reference to the Michigan Central Station:

How is it, then, that when we talk of progress in our cities we consistently fail to acknowledge the attendant concept of progression, an inherently organic act? No matter how much we negotiate and finagle and brainstorm and build up, the truth of the matter is, a city is as natural as a forest or a desert or an ocean. Its structures will ebb and flow and cycle much as the trees and the sand and the waves will. And like any sacred spot in the Hiawatha or the Mojave or the Pacific, under just the right circumstances—say a mild midwinter day with late-afternoon sunlight turning the sandstone a gloriously warm gold - one empty building among them all might be the most perfect place on earth. ${ }^{153}$

Recent dystopian tour guides published about Detroit echo this idea of the city's

urban nature as a site for reflection and aesthetic appreciation. In one, a tour guide published

in the Chicago Reader, the author argues:

A few hours' drive with no particular destination will take a visitor past not just overgrown mansions but abandoned skyscrapers, forgotten factories, burned-out bungalows, and swaths of wildflower-dappled urban prairie so large that you can forget you're in a major urban center. On the east side, whole neighborhoods already cleared by demolition and arson have been reclaimed by nature. Odd as it may sound, this is why you should visit Detroit now. If and when money ever comes in, you can be sure much of its eerie beauty will be lost forever. ${ }^{154}$

\footnotetext{
${ }^{152}$ See Matthew Gandy, "Cyborg urbanization: complexity and monstrosity in the contemporary city," International Journal of Urban and Regional Research 29, no. 1 (2005): 26-49.

153 Kristin Palm, "Ruins of a Golden Age," Metropolis, May 2002.

154 Jonathan Mahalak, "Wild wild Midwest," Chicago Reader, May 14, 2009.
} 
All of these versions of urban nature articulate different visions of the nonhuman world and by extension ourselves, as Jennifer Price has taught us. ${ }^{155}$ But despite their disagreement, these accounts use nonhuman imagery as a way of naturalizing Detroit's present state: Palm wants us to understand that cities themselves are natural and thus decay is at least partially inevitable, while Moore sees the particularity of Detroit as part of a broader story of humanity and the natural world locked in struggle. But there is a lack of precision in how these authors articulate what the natural world actually is. Most posit a version of the nonhuman that allows for popular understandings of nature to stand in as a partial explanation for what is happening in Detroit.

But it is an inherently faulty metaphor. Nature is not, and never has been static, and its meanings are inscribed by us as we use nature to articulate our own identities. Using natural metaphors as a way to describe Detroit's decline pulls on a particular construction of nature - as either violently destructive or else redemptive — to neutralize the processes that are presently constructing Detroit's landscape, most notably virulent racism and industrial restructuring. To subsume these processes in the comforting banality of abstracted nature is a way to, as Jerry Herron notes, "get over the responsibility of history."156 One need only think about Alan Weisman's bestselling The World Without Us, to understand the lure of a potential future in which the earth no longer has to deal with us. ${ }^{157}$ But these abstract imaginings of the city's disappearance ignore the complex entanglements between human

\footnotetext{
155 Jennifer Price, Flight Maps: Adventures with Nature in Modern America (New York: Basic Books, 1999).

156 Jerry Herron, "Three Meditations on the Ruins of Detroit," 35.

${ }^{157}$ Alan Weisman, The World Without Us (New York: Thomas Dunne Books, 2007).
} 
and nonhuman systems in favor of romanticized vision of a wild nature free from human involvement. The manicured parks and tree-lined streets of Detroit's suburbs like Grosse Pointe are as natural as the weeds growing in the city's abandoned lots, but they are much less documented.

All of this is to suggest that if we are to extend Palm's metaphor- that cities have natural life cycles - we have to think about what it actually means to suggest that cities are natural or unnatural. Rather than see nature as cyclical and stable, many scholars in Geography and beyond now conceive of ecosystems as contingent, hybrid, or in flux. Seeing nature as contingent and intertwined with urban space suggests that Detroit is not so much returning to nature as it is constructing new ecologies as it declines. This hurts the metaphorical potency of the natural reclamation idea, and suggests that the city's decline is not necessarily inevitable, nor is its reclamation by nature. Photographs of the city suggest the opposite, however, although so far in this paper I have only focused on the production of images in making that argument. This one-sided approach to representation ignores the complex politics associated with how images are received and engaged with. I turn now to the ways in which these images have been received and analyzed by readers and online commentators as a way of thinking about how these images function politically.

\section{Feral Detroit}


In July 2009, a Detroit-based blogger published a set of photos entitled "Feral Houses." of trees. There are 118 comments on the blog entry, and two of the photographs are for sale on a linked website. It is hard to establish a general thematic unity to how people have responded to images like these, but there is a general sense of melancholy, occasional celebratory moments, and quite a few references to Alan Weisman's The World Without Us. One commentator notes, "I am always amazed to re-realize that nature always wins.",159 Another:

The fragility of all our structure, our institutions, all our electronic gadgets, and plastic toys. The earth doesn't give two shits about it. It only seeks light and moisture and space to grow. Nature is completely indifferent to every single thing that man has built--whether we built in complete indifference to, in deference to, nature itself.

Another: "I love how the earth/plant life is just gobbling up stuff in its way. Dead wooden homes being mulched by ivy. the power of patience." Another: "go nature go! I agree with the commet that they are rippling with life -- not death." One of the many commentators who mentions Weisman's The World Without Us, notes:

Decay and reclamation are fascinating processes. Humans think this place is here for us but its not. As others have noted, those places missing a human presence are still teeming with life....As is described in "The World Without Us", even Chernobyl is being repopulated with wildlife whose lives are affected by the radiation but not thwarted. Gaia lives and she will do fine recreating balance with us or without us.

\footnotetext{
${ }^{158}$ Sweet Juniper blog. http://www.sweet-juniper.com/2009/07/feral-houses.html (accessed October 1, 2009).

${ }^{159}$ Comment on Sweet Juniper Blog. http://www.sweet-juniper.com/2009/07/feral-houses.html (accessed October 1, 2009). All comments found in this paper can be found on this link. Spelling and punctuation mistakes are included.
} 
One commentator pines, "I wish we could form new wagon trains of young people with energy, talent, and a love for old houses, and start a "40 acres and a shell" program to recolonize and revive Detroit using the personpower of those priced out of the undeserving cities back east. ..." Here, Detroit is reconceptualized as a kind of empty frontier awaiting colonization by noble homesteaders who have apparently forgotten that the city still boasts around 800,000 residents. Some even use images of Detroit's return to nature to blame unions, corruption, "gangbangers," and city planners, while one commentator notes, in an oft-repeated sentiment, "I find these pictures way more beautiful than sad. Better the houses get taken by nature than sit there rotting and being abused by humanity."

In a June 2010 update on the same blog entitled "(More) Feral Houses," commentators repeat many of the themes previously mentioned. One notes, "Beautiful. It's hard not to see this as some eternal struggle between humankind and nature....It's nice to see nature win--if just this once." ${ }^{160}$ Another notes that, "While I can see the author's point, I am pulling for mother nature to take back that which was used \& abused...consume it and keep marching forward." In his update, the author of the blog introduces the post by noting:

Nothing I have ever done has resonated as much as the photos of what I called 'feral houses' last summer. A quickly dashed-off blog post written while children tugged at my sleeves ended up capturing the attention of hundreds of thousands of people around the world and I still get hundreds of hits to that post every day. Even Alan Weisman, author of The World Without Us, e-mailed me about them. ${ }^{161}$

${ }^{160}$ Comment on Sweet Juniper Blog. http://www.sweet-juniper.com/2010/06/more-feral-houses.html (accessed July 10, 2010).

${ }^{161}$ Sweet Juniper Blog. http://www.sweet-juniper.com/2010/06/more-feral-houses.html (accessed July 10, 2010). 
I use the quote as an effort to quantify the appeal of these images, but it is ultimately difficult to get an accurate sense for how many people are viewing them. Sadly, the hundreds of thousands of people who have visited the site did not all comment. But clearly there is some kind of popular interest in these images, however difficult to quantify. Reposts of the initial blog entry can be found on a variety of websites, which gives further voice to the nerve that these particular images have struck. The comments on linked sites elucidate many of the same themes previously mentioned.

There are a few ways to think about these comments as expressions of broader anxieties. On a critical level, it is easy to see these comments as expressions of a particular kind of urban ambivalence, one linked to broader questions of racial formation and urban decline. As Jake Kosek has shown, ideas about nature are often articulated through hidden discourses of race and purity, allowing for nature to serve as a means by which racial categories are sedimented. The result is that struggles over wilderness are often struggles over purity and belonging, positing what Kosek calls "nature as always-already pure" against "the ever-threatening elements which 'have no right place in the landscape." 162 While the nature found in Detroit is decidedly murky, one nevertheless glimpses in these comments a lurking desire for nature to reclaim the city from the impure human touch. Given Detroit's long and ugly history of racial antagonism and the fact that it is at present nearly $90 \%$ African-American, it is possible to see these comments as part of an attempted erasure of

\footnotetext{
162 Jake Kosek, "Purity and Pollution: Racial Degradation and Environmental Anxieties," in Liberation Ecologies: Environment, Development, Social Movements, ed. Richard Peet and Michael Watts (London: Routledge, 2004), 53.
} 
African-American Detroiters from the landscape. In this context, I am forced to wonder who the commentator is referring to when he or she says "humanity."

But despite the linkages between fantasies of natural reclamation and racial purity, perhaps the kinds of urban ecologies found in places like Detroit present new urban formulations that have not yet been adequately theorized. The images and the responses to them express a sense anti-urbanism coupled with sadness and nostalgia, as cities like Detroit become increasingly unreadable and hard to make sense of. And these images could speak to a popular reworking of nature/culture binaries: Detroit is increasingly becoming known as a particularly hybrid metropolis, and to articulate what exactly that means is a question of fundamental importance.

\section{Conclusion}

In 2005, German artists based out of Detroit started a project called the Detroit Tree of Heaven Woodshop. ${ }^{163}$ The name is a reference to the famed Ailanthus Altisima, otherwise known as the Ghetto Palm, the Stink Tree, or the Tree of Heaven. Ailanthus is an aggressive invasive, capable of growing in sidewalk cracks and heavily disturbed soil, and it grows fast and reproduces faster. Over the past few years, the woodshop has used the tree as a way of calling into question the arbitrary divisions between urban and nature. They do this primarily by harvesting and curing the otherwise unusable wood, as well as a few comic installations: one tries to farm these trees and another transplants them to Germany to be purposefully grown. There is a lot of thick commentary imbedded in the project, and the idea of farming

163 Detroit Tree of Heaven Woodshop, http://treeofheavenwoodshop.com/ (accessed May 2010). 
an invasive plant gestures provocatively at the way in which ideas of nature are partially constructed. By attempting to use a local natural resource as a means of redevelopment for the city, the woodshop artists are raising interesting questions about redevelopment and urban ecology.

The woodshop seems to point at some of the openness of our current historical moment. Despite the voyeuristic dimension that is implicit in many of these representations of the city, it seems fair to say that we live in a time in which conceptual binaries- between urban and natural, in particular - are increasingly blurry, both scholarly and popularly. In the case of Detroit, our conceptual binaries seem be failing us, so rather than see nature in Detroit as a potential way forward for an urban future, commentators are often forced to see nature in the city as somehow oppositional. This has to do, in part, with an inability to understand the natural world as a place where we belong. As Bill Cronon argues:

We 'moderns' believe, even in a postmodern age, that we have the power to control the earth, despite our deep ambivalence about whether we know how to exercise that power wisely. On the other hand, our nostalgia for the more 'natural' world of an earlier time when we were not so powerful, when the human landscape did not seem so omnipresent, encourages us to seek refuge in pastoral or wilderness landscapes that seem as yet unscarred by human action. Convinced of our human omnipotence, we can imagine nature retreating to small islands - 'preserves' - in the midst of a landscape which otherwise belongs to us. And therein lies our dilemma: however we may feel about the urban world which is the most visible symbol of our human power-whether we celebrate the city or revile it, whether we wish to 'control' nature or 'preserve' it - we unconsciously affirm our belief that we ourselves are unnatural. Nature is the place we are not. ${ }^{164}$

164 William Cronon, Nature's Metropolis: Chicago and the Great West (New York: W.W. Norton \& Company, 1991), 18. 
Finding nature in Detroit is often a way to further ourselves from the natural systems we are invoking, as nature comes to function as a kind of partner to popular dystopian imaginations. Anxieties about climate change and overpopulation seem to animate much of these ideas, which are subsequently integrated into classical tropes about the immorality of cities. Whether we are talking about weeds growing in empty lots or manicured parks in the Detroit suburbs, nature in the city is a filter for broader ideas about race and urbanism that serve to divide human and nonhuman systems despite their incredible spatial proximity in this case. Much of this must have to do with the fact that the kinds of post-industrial urban ecologies seen in cities like Detroit have not yet been properly comprehended. The result is that urban ecologies come to function as counters to urbanism rather than examples of what Matthew Gandy calls "the co-evolutionary dynamics of social and bio-physical systems."165 Weeds growing in Detroit are as much a product of the city's materiality as they are a demonstration of the wild, yet they are often conceptualized as part of a return to nature rather than as part of a distinctly new and hybrid encounter. As both Gandy and Cronon make clear, new urban ecological imaginaries demand new conceptual languages and ideas, ways of imagining cities that resist binaries and analytic closure in favor of an openness to the ways that ecology, community and justice intersect. This involves noting that the return of nature to the city is not just a result of the city eroding, but a product of the city itself. As Gandy himself notes:

\footnotetext{
165 Matthew Gandy, "Urban Nature and the Ecological Imaginary," in In the Nature of Cities : Urban Political Ecology and the Politics of Urban Metabolism, ed. Nik Heynen, Maria Kaika and Erik Swyngedouw (London: Routledge, 2006), 72.
} 
By moving away from the idea of the city as the antithesis of an imagined bucolic ideal we can begin to explore the production of urban space as a synthesis between nature and culture in which long-standing antinomies lose their analytical utility and political resonance. ${ }^{166}$

Efforts to green Detroit through urban agriculture is one such way that a progressive urban ecology can serve to answer questions related to both social and environmental justice, and urban gardening suggests an idea of the natural world-Michael Pollan's Garden Ethic for instance - that privileges connectivity rather than opposition. ${ }^{167}$ This seems one way towards finding nature in the city in a way that is productive.

But since we are talking about landscape and representation, we need also find ways to represent nature in the city without reinforcing existing dualisms. This means more projects like the Tree of Heaven woodshop and Jef Geys' recent exhibit which tracks weeds and plants growing along Detroit's Woodward Avenue. These are potential ways forward for constructing these new urban ecological conceptualizations that privilege intersections and flows in the city rather than rely on nature as a co-conspirator in urban collapse. As Raymond Williams famously argued, nature is an extraordinarily complicated word. Finding ways to do justice to the incredible complexity of both human and nonhuman systems-especially as they interrelate in the unequal and divided spaces of the cities we inhabit - is one way towards a just urban ecology.

${ }^{166}$ Gandy, "Urban Nature and the Ecological Imaginary," 73.

${ }^{167}$ Michael Pollan, Second Nature: A Gardener's Education (New York: Grove Press, 1991). 


\section{Chapter 5: Conclusion}

Glemie Dean Beasley, a retired truck driver, has recently become a minor celebrity in Detroit. Known simply as the "coon man" due to the fact that he hunts and sells raccoons to eat, Beasley has played host to a series of reporters and journalists over the past two years. ${ }^{168}$ His story is almost perfectly suited to a particular Detroit narrative, and he noted in an April news story, “"This city is going back to the wild. That's bad for people but that's good for me. I can catch wild rabbit and pheasant and coon in my backyard." ${ }^{169}$ Like many Detroit discourses, the tale of the coon man has spread far, appearing in national newspapers and a host of blogs and websites. Barbara Ehrenreich used him as an example in a June 2009 editorial on the recession, and the writers for the New York Times' Freakonomics blog noted in August 2009, "Detroit is practically a giant food desert, with no produce-carrying grocery chains left and its citizens resorting to local raccoon and pheasant meat." ${ }^{170}$ Beasley was even a key component of an NBC Dateline special on the city in April 2010, and his inclusion prompted a minor outcry by Detroiters, most of whom do not actually hunt raccoons within the city limits and are somewhat wary of the racial connotations of the term “coon."171

\footnotetext{
${ }^{168}$ See Charlie LeDuff, “To Urban Hunter, Next Meal is Scampering By," The Detroit News, April 2, 2009. Michael Moore's film Roger \& Me also features a scene in which an unemployed Detroiter hunts and sells local animals for food. See Wolfgang Natter and John Paul Jones, III, "Pets or Meat: Class, Ideology, and Space in Roger \& Me, Antipode 25, no. 2 (2006), 140-158.

169 LeDuff, "To Urban Hunter, Next Meal is Scampering By."

${ }^{170}$ Barbara Ehrenreich, "Too Poor to Make the News," New York Times, June 13, 2009; Freakonomics Blog, "Detroit Produce City?" http://freakonomics.blogs.nytimes.com/2009/08/04/detroit-produce-city/.

${ }^{171}$ Chris Hansen, Dateline NBC, "America Now: City of Heartbreak and Hope," April 20, 2010.
} 
Nevertheless, the story of Beasley is a fitting way to tie together two of the central arguments of this paper. On one hand, his tale is clearly representative of the citationality and reproducibility of imaginative geographies. The way in which his story has circulated demonstrates how quickly and easily narratives can be altered. The quick discursive shift from Beasley as one man to Detroit as a city where many live off of raccoon meat is the same kind of change that one can see in many stories about Detroit. It does not seem far-fetched to suggest that visitors to Detroit—or, more accurately, people who refuse to visit Detroit—will find their experiences altered by stories like that of the Coon Man.

And secondly, stories like Beasley's are fast becoming one of the common ways in which Detroit is understood as a kind of rural city, a place whose devastation is so thorough that it threatens to blur divisions between the natural and the urban. As Jerry Herron notes in a recent article:

Detroit sits precisely at the border of city and not-city....Here, the fearful energy released by a city in decay raises questions not only about the economic and governmental systems that produced Detroit (and America), but also about the humanity of citizens so transformed by urbanism that they can visit upon each other all the miseries and cruelty locally deployed. ${ }^{172}$

Herron is in part responding to Rebecca Solnit, whose article, Detroit Arcadia, is one of the more provocative and compelling accounts of the city published in the past few years. ${ }^{173}$ It is undeniably a part of why I came to study Detroit in the first place, and it seems to function as a touchstone for many with an interest in the city. Solnit's article predates much of the recent attention Detroit has received, and despite my distaste for the narratives

\footnotetext{
172 Herron, "Borderland/Borderama/Detroit," unpaginated.

173 Solnit, "Detroit Arcadia."
} 
that suggest the city is returning to nature, articles like Solnit's make it clear that there is something at work in Detroit that is actually quite fascinating. As Solnit herself notes, "Having a city grow up around you is not an uncommon American experience, but having the countryside return is an eerier one."174 For Solnit, Detroit's landscape is not yet postapocalyptic, but instead "post-American," and she chronicles the efforts to start gardening and greening the city in the wake of the city's decline. ${ }^{175}$ Her account of the city is warmer than most.

Solnit retells the familiar story of pheasants in the city, and gives readers a third version of how to interpret them. For Vergara, these pheasants were a metaphor for redemption whereas photographer Andrew Moore saw them as a symbol of the eternal struggle between the works of people and the forces of nature. Solnit gives them a bit more nuance, and argues that the sight of two pheasants in the city "was an improbable flight in many ways." She continues:

Those pheasants, after all, were no more native to Detroit than are the trees of heaven growing in the skyscrapers downtown. And yet it is here, where European settlement began in the region, that we may be seeing the first signs of an unsettling of the very premises of colonial expansion, an unsettling that may bring a complex new human and natural ecology into being. This is the most extreme and long-term hope Detroit offers us: the hope that we can reclaim what we paved over and poisoned, that nature will not punish us, that it will welcome us home - not with the landscape that was here when we arrived, perhaps, but with land that is alive, lush, and varied all the same. ${ }^{176}$

\footnotetext{
${ }^{174}$ Ibid., 72.

${ }^{175}$ Ibid., 66.

${ }^{176}$ Ibid., 73
} 
Solnit uses an understanding of the nonhuman as contingent and flexible in order to complicate Detroit's trajectory. Rather than reduce the story to easy tales of natural reclamation, Solnit admits that the nature emerging in Detroit is new and presents an ecology that is undeniably in the making. These forms of "metropolitan nature," as Matthew Gandy refers to them, are an increasing component of cities like Detroit. They are a part of the story of the city, and they need to be complicated and deepened. Just what is nature in Detroit? And what does our collective interest in it say about how we understand nature? And by extension: ourselves?

But there is another story that needs to be told about Detroit as well, and it is a story about connectivity rather than distance. Narratives of Detroit often stress the city's disconnection from mainstream societal values, as part of what sociologist Loïc Wacquant calls the "tendency to exoticize the [American] ghetto.",177 This tendency is part of what Jerry Herron is responding to, when he asks, in reference to Detroit's standing as the most dangerous city in America:

Is this really a singular case - the case of a city committing cultural suicide or homicide? Or is it a case of something broader and more generally shared - a city being done in by the racialization of poverty and crime in America, with this place only making more visible things that exist — homicidally across our culture? In this context, it's not the actual border that counts, but the way the border gets represented, as a means of separating things we want to believe from things we want to believe aren't relevant because they apply to somebody else. ${ }^{178}$

\footnotetext{
${ }^{177}$ Loïc J.D. Wacquant, “Three Pernicious Premises in the Study of the American Ghetto," International Journal of Urban and Regional Research 20 (June 1997), 342.

${ }^{178}$ Herron, "Borderland/Borderama/Detroit," unpaginated.
} 
Part of this involves starting to think about cities like Detroit as what Jennifer Robinson calls "ordinary cities." 179 Robinson is referring to the cities of the Global South, but the idea fits: Detroit is often referred to as an underdeveloped city that feels decidedly unAmerican, although one could also probably argue that a devastated inner city surrounded by affluent suburbs is the quintessential American urban form. Regardless, to begin to see Detroit not as other but as ordinary suggests that we begin to see Detroit's ongoing collapse — and not just its history — as part of processes that are still occurring. This means switching an aesthetic engagement for a political engagement in Detroit. It also involves tracing the geographies of race and class as they flow in and out of the city, and finding ways to see Detroit as an ongoing phenomenon rather than a finished product. And it involves seeing the ways in which the city is represented as part of that stor

${ }^{179}$ Jennifer Robinson, Ordinary Cities: Between Modernity and Development (New York: Routledge, 2006). 


\section{Bibliography}

Altman, Alex. 2009. Detroit tries to get on a road to renewal. Time, March 26.

Beardsley, John. 2007. Art or Eyesore? In Connecting the Dots: Tyree Guyton's Heidelberg Project, ed. The Heidelberg Project, XX-XX. Detroit: Wayne State University Press.

Beauregard, Robert. 2003. Voices of Decline: the Post-war Fate of U.S. Cities, $2^{\text {nd }}$ ed. New York: Routledge, 2003.

-2005. Images of Renewal and Decline. Paper presented at "Beyond the PostIndustrial City," November 18, in Camden, NJ.

Berman, Marsfhall. 1987. Among the Ruins. New Internationalist 178, unpaginated.

Boileau, Lowell. Tour Detroit. http://www.detroityes.com/0tourdetroit.htm. (accessed Feburary 15, 2009).

—.The DetroitYES! Project. http://www.detroityes.com/0aboutthissite.htm (accessed February 15, 2009).

Chafets, Ze'ev.1990. Devil's Night: And Other True Tales of Detroit. New York: Random House.

Chervokas, Jason, and Tom Watson. 1998. Digital Monuments to the Urban Past. New York Times, March 1.

Cronon, William.1991. Nature's Metropolis: Chicago and the Great West. New York: W.W. Norton \& Company. .1995. The Trouble with Wilderness, or, Getting Back to the Wrong Nature. In Uncommon Ground: Rethinking the Human Place in Nature, ed. William Cronon, 69-90. New York: W.W. Norton \& Co., 1995.

Cosgrove, Dennis E. 1998 [1984]. Social Formation and Symbolic Landscape. Madison, WI: The University of Wisconsin Press, 1998.

Daniels, Stephen. 1993. Fields of vision : landscape imagery and national identity in England and the United States. Cambridge: Polity Press.

Dennis Jr., Samuel F. 2006. Seeing Hampton Plantation: Race and Gender in a South Carolina Heritage Landscape. In Landscape and Race in the United States, ed. Richard H. Schein, 73-94. New York: Routledge.

DeSilvey, Caitlin. 2006. Observed Decay: Telling Stories with Mutable Things. Journal of Material Culture 11, no. 3: 318-338. . 2007a. Salvage Memory: Constellating Material Histories on a Hardscrabble Homestead. Cultural Geographies 14, no. 3: 401-424. 
- 2007b. Art and archive: Memory-work on a Montana Homestead. Journal of Historical Geography 33: 878-900.

Detroit Design Guide, Design*Sponge. http://www.designspongeonline.com/2008/01/detroitdesign-guide.html. (accessed June 15, 2009).

Detroit's Horrible, Beautiful Decline: Two French photographers immortalize the remains of the motor city on film. Time.com. http://www.time.com/time/photogallery/0,29307,1882089,00.html. (accessed April 15, 2009).

Detroit Tree of Heaven Woodshop. Http://treeofheavenwoodshop.com. (accessed May 2, 2010).

Dybis, Karen. 2010. Art or Exploration? The Detroit Blog, July 1.

Edensor, Tim. 2005a. Industrial Ruins: Spaces, Aesthetics and Materiality. Oxford: Berg.

— 2005b. Waste Matter - The Debris of Industrial Ruins and the Disordering of the Material World. Journal of Material Culture 10, no. 3: 311-332.

- 2005c. The Ghosts of Industrial Ruins: Ordering and Disordering Memory in Excessive Space. Environment and Planning D: Society and Space 23: 829-849.

Ehrenreich, Barbara. 2009. Too Poor to Make the News. New York Times, June 13.

Freakonomics Blog. Detroit Produce City? http://freakonomics.blogs.nytimes.com/2009/08/04/detroit-produce-city.

Free Press Editorial. 2009. One last chance for ghost depot. Detroit Free Press, April 26.

Free Press Editorial. 2009. Get the message, Moroun and City: Do Something about Train Depot. Detroit Free Press, April 9.

Fyfe, Gordon, and John Law. 1988. Picturing Power: Visual Depiction and Social Relations. London: Routledge.

Gandy, Matthew. 2005. Cyborg urbanization: complexity and monstrosity in contemporary city. International Journal of Urban and Regional Research 29, no. 1: 26-49.

- 2006. Urban Nature and the Ecological Imaginary. In In the Nature of Cities : Urban Political Ecology and the Politics of Urban Metabolism, ed. Nik Heynen, Maria Kaika and Erik Swyngedouw, 63-74. London: Routledge.

Gerritt, Jeff. 2009. Detroit’s “Ellis Island” still impresses. Detroit Free Press, April 26. . 2009. ...And Ridding the City of its Major Symbols of Decay. Detroit Free Press, November 1. 
Gillette, Jr., Howard. 2005. Camden After the Fall. Philadelphia: University of Pennsylvania Press.

Gregory, Derek. 1995. Between the Book and the Lamp: Imaginative Geographies of Egypt, 1849-50. Transactions of the Institute of British Geographers 20, no.1: 29-57.

—. 2000. Edward Said's Imaginative Geographies. In Thinking Space, ed. Mike Crang and Nigel Thrift, 302-348. London: Routledge.

-2003. Emperors of the Gaze: Photographic Practices and Productions of Space in Egypt, 1839-1914. In Picturing Place: Photography and the Geographical Imagination, ed. Joan Schwartz and James Ryan, 195-225. London: I.B. Tauris.

— 2004. The Colonial Present: Afghanistan, Palestine, Iraq. Malden, MA: Blackwell Publishing.

Guyton, Tyree. 2007. From the Artist. In Connecting the Dots: Tyree Guyton's Heidelberg Project, v-vii. Detroit: Wayne State University Press.

Hansen, Chris. 2010. Dateline NBC. "America Now: City of Heartbreak and Hope,” April 20.

Harvey, David. 1990. The Condition of Postmodernity: An Enquiry into the Origins of Cultural Change. Cambridge, MA: Blackwell Publishing.

Harvey, David. 1989. From Managerialism to Entrepreneurialism: The Transformation in Urban Governance in Late Capitalism. Geografiska Annaler B 71: 3-17. 1993. The Nature of Environment: Dialectics of Social and Environmental Change. In Real Problems, False Solutions. London: The Merlin Press.

Headlee, Celeste. 2009. An abandoned symbol of Detroit's better days. NPR, June 2. http://www.npr.org/templates/story/story.php?storyId=104873009. (accessed June 5, 2009).

. 2010. Is 'Ruin Porn' Art or Journalism? The Takeaway, July 6.

Herron, Jerry. 1993. AfterCulture: Detroit and the Humiliation of History. Detroit: Wayne State University Press.

- 2002. Three Meditations on the Ruins of Detroit. In Stalking Detroit, ed. Georgia Daskalakis, Charles Waldheim, and Jason Young, 33-41. Barcelona: Actar.

-2010. Borderland/Borderama/Detroit. The Design Observer Group, July 8.

Heynen, Nik, Maria Kaika, and Erik Swyngedouw. 2006. Urban Political Ecology: Politicizing the Production of Urban Natures. In In the Nature of Cities: Urban Political Ecology and the Politics of Urban Metabolism, ed. Nik Heynen, Maria Kaika, and Erik Swyngedouw, 1-20. London: Routledge. 
Hodges, Michael. 2007. Heidelberg and the Community. In Connecting the Dots: Tyree Guyton's Heidelberg Project. Detroit: Wayne State University Press, 49-69.

Huyssen, Andreas. 2006. Nostalgia for Ruins. Grey Room 23: 7-21.

Josar, David. 2009. Detroit council votes to demolish Michigan Central Depot, charge owner. Detroit News, April 8.

Judd, Dennis R. 1999. Constructing the Tourist Bubble. In The Tourist City, ed. Dennis R. Judd and Susan S. Fainstein, 35-53. New Haven: Yale University Press.

Kosek, Jake. 2004. Purity and Pollution: Racial Degradation and Environmental Anxieties. In Liberation Ecologies: Environment, Development, Social Movements, ed. Richard Peet and Michael Watts, 125-155. London: Routledge.

LeDuff, Charlie. 2009. To Urban Hunter, Next Meal is Scampering By. The Detroit News, April 2, 2009.

Lange, Amy. 2006. eCommunity: Detroit YES' Lowell Boileau. Real Detroit Weekly, August 9.

Leitner, Helga, and Eric Sheppard. 1998. Economic Uncertainty: Inter-Urban Competition and the Efficacy of Entrepreneurialism. In The Entrepreneurial City: Geographies of Politics, Regime and Representation, ed. Tim Hall and Peter Hubbard, 285-308. Chichester: John Wiley \& Sons.

Lewis, Pierce. 1979. Axioms for Reading the Landscape. In The Interpretation of Ordinary Landscapes, ed. D.W. Meinig, 11-32. New York: Oxford University Press.

McGraw, Bill. 2007. Historians in the Streets: Life in the Ruins of Detroit. History Workshop Journal 63: 289-302.

Mahalak, Jonathan. 2009. Wild wild Midwest. Chicago Reader, May 14.

Marchard, Yves, and Romain Meffre. (forthcoming). The Ruins of Detroit. London: Steidl.

Marchand, Yves, and Romain Meffre. The remains of Detroit. Yves Marchand and Romain Meffre Photography. http://www.marchandmeffre.com/detroit/index.html. (accessed April 15, 2009).

McGraw, Bill. 2009. Web site captures decline of Detroit's iconic train depot. Detroit Free Press, April 9.

Mitchell, Don. 1996. The Lie of the Land: Migrant Workers and the California Landscape. Minneapolis, MN: University of Minnesota Press.

Mitchell, W.J.T. 1994a. Introduction. In Landscape and Power, ed. W.J.T. Mitchell, 1-4. Chicago: The University of Chicago Press. 
.1994b. Imperial Landscape. In Landscape and Power, ed. W.J.T.Mitchell, 5-34. Chicago: The University of Chicago Press.

Moore, Andrew. 2010. Detroit Disassembled. Akron, Ohio: Akron Art Museum.

Morton, Thomas. 2009. Something, Something, Something, Detroit. Vice, August.

Natter, Wolfgang, and John Paul Jones, III. 2006. Pets or Meat: Class, Ideology, and Space in Roger \& Me. Antipode 25, no. 2:140-158.

Odede, Kennedy. 2010. Slumdog Tourism. The New York Times, August 10.

O, Kelly. 2010. Things I Remember About Detroit: Five Years of Abandoned Factories, Talking Cats, and Cars on Fire. The Stranger, May 25.

Pagano, Michael A., and Ann O’M. Bowman. 1997. Cityscapes and Capital: The Politics of Urban Development. Baltimore: The Johns Hopkins University Press.

Palm, Kristin. 2002. Ruins of a Golden Age. Metropolis, May.

Parks, Brian. 2005. Going to Detroit. The New York Times, August 28.

Pollan, Michael. 1991. Second Nature: A Gardener's Education. New York: Grove Press.

Price, Jennifer. 1999. Flight Maps: Adventures with Nature in Modern America. New York: Basic Books.

Reed, John. 2009. The Travails of Detroit. Financial Times, March 6.

Robinson, Jennifer. 2006. Ordinary Cities: Between Modernity and Development. New York: Routledge.

Rose, Gillian. On the Need to Ask How, Exactly, Is Geography 'Visual'? Antipode 35, no. 2: 212-221.

Ryan, James R. 1997. Picturing Empire: Photography and the Visualization of the British Empire. London: Reaktion Books.

Rybczynski, Witold. Detroit's Beautiful Ruins. Slate.com, http://www.slate.com/id/2213696/slideshow/2213979/entry/2213981/fs/0//. (accessed January 15 2010).

Said, Edward W. 1979. Orientalism. New York: Vintage Books. .1993. Culture and Imperialism. New York: Knopf.

Said, Edward W., and Jean Mohr. 1986. After the Last Sky: Palestinian Lives. New York: Pantheon Books.

Saulny, Susan. 2010. Seeking a Future for a Symbol of a Grander Past. The New York Times, March 5. 
Schein, Richard H. 1997. The Place of Landscape: A Conceptual Framework for Interpreting an American Scene. Annals of the Association of American Geographers 87, no. 4: 660-680.

-.Normative Dimensions of Landscape. 2007. In Everyday America:

Cultural Landscape Studies after J.B. Jackson, ed. Chris Wilson and Paul Groth, 199-218. Berkeley: University of California Press.

Schwartz, Joan. 1996. The Geography Lesson: Photographs and the Construction of Imaginative Geographies. Journal of Historical Geography 22, no. 1: 16-45.

Schwartz, Joan, and James Ryan, ed. 2003. Picturing Place: Photography and the Geographical Imagination. London: I.B. Tauris.

Shea, Bill. 2009. Detroit city council wants Michigan central depot torn down. Crain's Detroit Business, April 7.

Sheridan, David. 1999. Making Sense of Detroit. Michigan Quarterly Review 38, no.3: 321353.

Simmel, Georg. 1959 [1911]. The Ruin. In Georg Simmel, 1858-1918: A Collection of Essays, with Translations and a Bibliography, ed. Kurt H. Wolfe, 259-266.

Columbus, OH: Ohio State University Press, 1959.

Skrdla, Harry. 2006. Ghostly Ruins: America's Forgotten Architecture. New York: Princeton Architectural Press.

Smith, Neil. 1996. The New Urban Frontier: Gentrification and the Revanchist City. London: Routledge.

Solnit, Rebecca. 2007. Detroit Arcadia: Exploring the Post-American Landscape. Harper's Magazine 315: 65-73.

Steinmetz, George. 2008. Harrowed Landscapes: White Ruingazers in Namibia and Detroit and the Cultivation of Memory. Visual Studies 23, no. 3: 211-237.

Still No Decision on Old Depot's Future. 2009. My Fox Detroit, May 18. http://www.myfoxdetroit.com/dpp/news/local/090518_train_depot.

Sweet Juniper blog. http://www.sweet-juniper.com/2009/07/feral-houses.html (accessed October 1, 2009).

Tearing down will not stimulate. 2009. The Michigan Citizen. April 12.

"The Remains of Detroit," Time.com, http://www.time.com/time/photogallery/0,29307,1864272_1810098,00.html (accessed December 20, 2008).

Vergara, Camilo José. 1996. American Acropolis, New Statesmen \& Society 9, no. 385. 
—. 1997. The New American Ghetto. New Jersey: Rutgers University Press.

_.1999a. American Ruins. New York: Monacelli Press.

- 1999b. Michigan Central Railroad Station, Detroit. Michigan Quarterly Review, 38, no. 3 .

Wacquant, Loïc J.D. 1997. Three Pernicious Premises in the Study of the American Ghetto. International Journal of Urban and Regional Research 20: 341-353.

Weisman, Alan. 2007. The World Without Us. New York: Thomas Dunne Books.

Walters, Wendy S. 2001. Turning the Neighborhood Inside Out: Imagining a New Detroit in Tyree Guyton's Heidelberg Project. The Drama Review 45, no. 4: 64-93.

Williams, Corey. 2009. Detroit wants blighted old train depot demolished. USA Today, April 7.

Williams, Raymond. 1980. Ideas of Nature. In Culture and Materialism, XX-X.London: Verso.

Wojdyla, Ben. 2009. The Feral Factories of Detroit. Jalopnik.com, August 5. 